\title{
Acoustics in Historical Buildings; Case of Gazi University Rectorate Building Mimar Kemaleddin Hall
}

\author{
Fusun Demirel \\ Faculty of Architecture, Department of Architecture, \\ Gazi University, Ankara, Turkey \\ E-mail: fusund@gazi.edu.tr \\ Merve Gorkem \\ MEGO Dan. Mim. Ins. San. ve Tic. Ltd. Sti. \\ Ankara, Turkey \\ E-mail: info@megodanismanlik.com \\ Seniha Soyal \\ Faculty of Architecture, Department of Architecture, \\ Gazi University, Ankara, Turkey \\ E-mail: snh_syl@hotmail.com
}

\begin{abstract}
It presents the difficulty of renovation and updating in accordance with the original for the restoration of historical buildings, the preservation of historical buildings and their transfer to the future. Along with many disciplines, the acoustic field often finds itself at the center of this challenge, and they encounter traditional solutions that must meet contemporary acoustic requirements. In multi-purpose halls serving different functions such as conferences and concerts; acoustic conditions that are contradicting and very different from each other must be provided in the same volume. Although the location and angle of the panels are important to reduce the reverberation time and improve the acoustic characteristics, maintain aesthetics and follow historical preservation instructions, it is important to evaluate the physical properties of the hall. The ODEON (v 15.14) Simulation Program analyzes and evaluations related to the acoustic design developed in this context were evaluated separately for each function.
\end{abstract}

Keywords: Acoustics in historical buildings, conference hall, concert hall, architectural acoustics

DOI: $10.7176 /$ JSTR/6-07-05

\section{Tarihi Binalarda Akustik; Gazi Üniversitesi Rektörlük Binası Mimar Kemaleddin Salonu Örneği}

\begin{abstract}
Özet
Tarihi binaların restorasyonu, tarihi yapıların korunması, geleceğe aktarılmasını için aslına uygun biçimde yenileme ve güncelleme zorluğunu sunmaktadır. Birçok disiplin ile birlikte akustik alanı da sık sık kendisini bu zorluğun merkezinde bulur ve çağdaş akustik gereklilikleri yerine getirmesi gereken geleneksel çözümlerle karşılaşırlar. Konferans ve konser gibi farklı işlevlere hizmet veren, çok amaçlı salonlarda; birbiri ile çelişen ve birbirinden çok farklı akustik koşulların, aynı hacim içerisinde sağlanması gerekmektedir. Reverberasyon süresini azaltmak ve akustik karakteristiğini geliştirmek, estetiği korumak ve tarihi koruma talimatlarını takip etmek için panellerin uygulanacağı konum ve açı önemli olmakla birlikte, salonun fiziksel özelliklerinin de değerlendirilmesi önem taşımaktadır. Bu bağlamda geliştirilen akustik tasarıma ilişkin ODEON (v 15.14) Simülasyon Programı analizleri ve değerlendirilmeleri her işleve yönelik olarak ayrı ayrı ele alınarak değerlendirilmiştir.
\end{abstract}

Anahtar Kelimeler: Tarihi binalarda akustik, konferans salonu, konser salonu, mimari akustik 


\section{Giriş}

Şehirlerimizi karakterize eden tarihi binaların restorasyonu, bize tarihi yapıların korunması, geleceğe aktarılmasını için aslına uygun biçimde yenileme ve güncelleme zorluğunu sunmaktadır. Birçok disiplin ile birlikte akustik alanı da sık sık kendisini bu zorluğun merkezinde bulur ve çağdaş akustik gereklilikleri yerine getirmesi gereken geleneksel çözümlerle karşılaşırlar. Geleneksel çözümlerin performansını artırmak için teknik iyileştirmeler uygulamak amacıyla ilk adım, bu çözümlerin gerçek yaşam koşullarında nasıl çalıştığını ve performans gösterdiğini anlamaktır [1,2].

Tarihi binalardaki performans salonlarında estetik ve tarihi nedenlerden dolayı akustik iyileştirmeler için ses yutucu ve yansitıcı panellerin uygulanmasının ve kullanılacak malzemenin türünü ve akustik iyileştirmenin en etkin konum ve geometrisini bulmanın zor olduğu bir gerçektir [3].

Konferans ve konser gibi farklı işlevlere hizmet veren, çok amaçlı salonlarda; birbiri ile çelişen ve birbirinden çok farklı akustik koşulların, aynı hacim içerisinde sağlanması gerekmektedir. Reverberasyon süresini azaltmak ve akustik karakteristiğini geliştirmek, estetiği korumak ve tarihi koruma talimatlarını takip etmek için panellerin uygulanacağı konum ve açı önemli olmakla birlikte, salonun fiziksel özelliklerinin de değerlendirilmesi önem taşımaktadır [3].

\section{Yöntem}

Çalışmada, öncelikle mevcut restorasyon projesi kapsamında mimari tasarım parametrelerine yönelik hem plan hem kesit düzleminde ışın analizleri ile kaynaktan çıkan direk ses ve ilk yanal yansıyan seslerin analizleri yapılmıştır. Salon ile ilgili; salonun formu, kişi başına düşen hava hacmi, salonun en-boyyükseklik oranları, izleyici oturma alanı, sahne özellikleri ve balkon tasarımı literatürde önerilen akustik parametreler doğrultusunda değerlendirilmiştir.

Uygun olan akustik koşulların sağlanabilmesi amacıyla salonda; duvar, döşeme ve asma tavan malzemelerini kapsayan iyileştirmeler yapılarak salon tasarımı sabit tutulmuş, konferans ve konser işlevlerine yönelik uygun akustik tasarım parametreleri sahnede "Birleşen Hacimler Sistemi (Coupled Volumes System)" ve Akustik Perde Sistemi (Acoustic Curtains) tasarımı aracıllğı ile sağlanma yoluna gidilmiştir. Bu bağlamda geliştirilen akustik tasarıma ilişkin ODEON (v 15.14) Simülasyon Programı analizleri ve değerlendirilmeleri her işleve yönelik olarak ayrı ayrı ele alınarak değerlendirilmiştir. Tasarımda yer alan malzemeler; Odeon malzeme kütüphanesi ve laboratuvar test raporları bulunan ürünler içerisinden seçilmiştir. Benzetim çalışmalarında seçilen malzemelerin ses yutma katsayıları kullanılmıştır $[4,5]$.

\section{Salon Hakkında Genel Bilgiler}

Bugün Gazi Üniversitesi Rektörlük Binası olarak kullanılan ve 1927 tarihinde "Gazi Mustafa Kemal Paşa Muallim Mektebi" olarak temeli atılmış olan yapı Mimar Kemaleddin'in son eseridir. Mimar Kemaleddin'in Ankara Gazi İlk Muallim Mektebi binası daha sonra, Kültür ve Turizm Bakanlı̆ğ Taşınmaz Kültür ve Tabiat Varlıkları Yüksek Kurulu'nun 1984 tarihindeki karar ile Gazi Üniversitesi'nin Rektörlük binası olmuştur. Binada girişin tam karşısına, iki kat yüksekliğinde, balkonu ve sahnesi olan büyük bir toplantı salonu, günümüzdeki adıyla Mimar Kemaleddin Salonu, yerleştirilmiştir [6]. Salona ait mevcut durumuna yönelik bilgiler Tablo1'de verilmiştir.
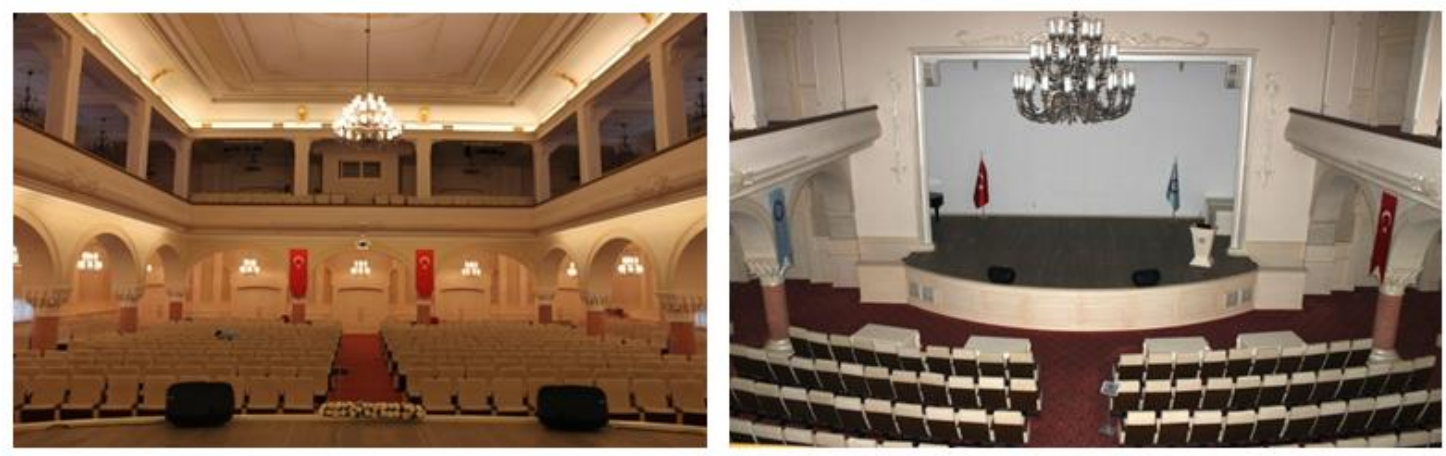

Şekil 1. Salon mevcut durum görünüşleri 
Tablo 1. Mimar Kemaleddin Salonu mevcut durum özellikleri

\begin{tabular}{|l|l|l|l|}
\hline & Alt & Balkon & Sahne \\
\hline Hacim (m3) & $2600+790 \mathrm{~m} 3$ & $1150 \mathrm{~m} 3$ & $220 \mathrm{~m} 3$ \\
\hline Ortalama en (m) & $\begin{array}{l}14 \mathrm{~m} \text { (koltuk alanı) } \\
23,45 \mathrm{~m} \text { (salon) }\end{array}$ & $\begin{array}{l}13,9 \mathrm{~m} \text { (koltuk alanı) } \\
23,45 \mathrm{~m} \text { (salon) }\end{array}$ & $15,1 \mathrm{~m}$ \\
\hline Ortalama boy (m) & $\begin{array}{l}21 \mathrm{~m} \text { (koltuk alanı) } \\
23,75 \mathrm{~m} \text { (salon) }\end{array}$ & - & $7,5 \mathrm{~m}$ \\
\hline Ortalama yükseklik (m) & $9 \mathrm{~m}$ & $4,75 \mathrm{~m}$ & $\begin{array}{l}6,40 \mathrm{~m} \\
\text { (sahne +0.75) }\end{array}$ \\
\hline Döşeme alanı (m2) & $\begin{array}{l}490 \mathrm{~m} 2 \\
\text { (koltuk alanı: } 220 \mathrm{~m} 2)\end{array}$ & $\begin{array}{l}370 \mathrm{~m} 2 \\
\text { (koltuk alanı: } 80 \mathrm{~m} 2)\end{array}$ & $\begin{array}{l}35 \mathrm{~m} 2(\text { ön sahne) } \\
38 \mathrm{~m} 2\end{array}$ \\
\hline Koltuk sayısı & 378 & 79 & - \\
\hline Ön sahne açıklığı & $\begin{array}{l}972 \mathrm{~cm}(\text { en) } \\
628 \mathrm{~cm} \text { (boy) }\end{array}$ & & \\
\hline
\end{tabular}

\section{Mimari Tasarım Parametrelerine Yönelik Akustik Performans Kriterleri}

Mimar Kemaleddin Salonu'nun mevcut koşullarının (Restorasyon) mimari tasarım parametrelerine yönelik akustik performans kriterleri çerçevesinde değerlendirilmesi Tablo 2 ve Tablo 3 'de sunulmuştur. Değerlendirmeler konferans ve konser işlevi ele alınarak ve tarihi korunan binalar kapsamında sınırlılıklar göz önünde bulundurularak yapılmıştır. Değerlendirmeler sonucunda uygun olmayan koşullara yönelik düzenleme önerileri aşağıda sıralanmaktadır:

- Hacim değerlendirmesi yapıldığında; hacmin konuşma işlevine uygun olmadığı görülmüştür. Birleşen Hacimler Sistemi (Coupled Volumes System) tasarlanması ile salonun hava hacmi işleve uygun şekilde değiştirilecektir.

- Yükseklik/genişlik oranı 0,7'den büyük olması beklenmektedir. Ancak proje restorasyon projesi olması nedeniyle bu değer sınırlılıklar kapsamında değiştirilmesi mümkün olamamıştır.

- İzleyici oturma alanından görüş performansı değerlendirildiğinde; genişlik ve uzunluk optimum aralıkta yer alsa da mevcut döşemenin düz (eğimsiz) olması nedeniyle görüş izleyici alanın yarısından itibaren zayıflamaktadır. Görüş performansının iyileştirilmesine yönelik olan eğim ihtiyacı projenin restorasyon kararları doğrultusunda mümkün değildir.

- Konser işlevine yönelik salonlarda balkon altında bulunan; izleyici alanının derinliği/ balkon altı yüksekliği değeri 1'den küçük olması beklenmektedir. Elde edilen değer 1'e çok yakın olmakla beraber izleyici sırasının sondan bir öndeki sıra için bu değer sağlanmaktadır. Ayrıca balkon altında kalan izleyici alanının son sırasındaki izleyici için düşey görüş açısı 40 dereceyi sağlaması gerekirken bu değer 34 derece olarak tespit edilmiştir (Şekil 2). Bu açının ve derinlik/yükseklik oranının sağlanması için izleyici alanının son sırasının kaldırılması önerilmektedir.

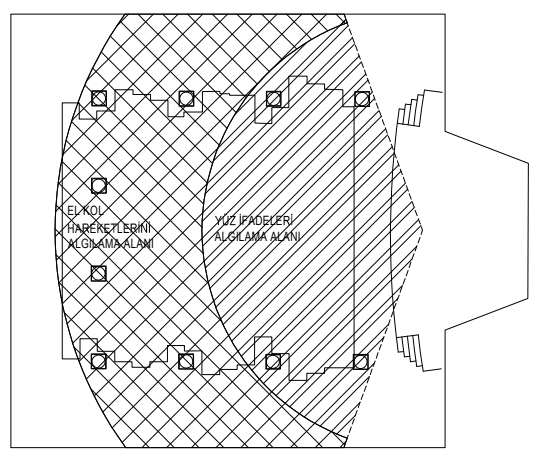

(a)

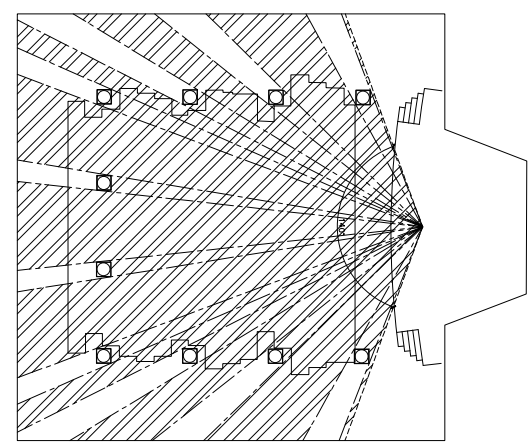

(b)

Şekil 2. İzleyici oturma alanının görüş durumu 
Şekil 2 (a ve b)'de belirtilen izleyicilerin görüş durumu plan düzleminde incelemeler doğrultusunda; tüm alanda görüş sağlanmaktadır. İzleyici alanın en uzak noktasının kaynak noktaya uzaklığ 20 m mesafe içerisinde; ilk $12 \mathrm{~m}$ içerisinde olanlar yüz ifadelerini algılayabilecek, geri kalan kısım ise el-kol hareketlerini algılayabilecek mesafededir. Ancak izleme durumu ile ilgili kesit düzleminde incelendiğinde Şekil 3'te görüldüğü üzere S1 kaynağ1 için oturma düzenin yedinci sırasından sonra görüş için gerekli $10 \mathrm{~cm}$ sağlanamamakta ve görüş zayıflamaktadır. Görüş için Tablo 3'de verilmiş olan; $d=\mathrm{T} /$ [F-E] denkleminde değerler yerlerine koyulduğunda, d (görüşün sağlandığı son uzaklık) değeri 9,975 olarak tespit edilmiştir. Bu değer de daha önce bahsedildiği gibi oturma düzenin yedinci sırasına denk gelmektedir. Ancak proje, restorasyon projesi olması nedeniyle bahsedilen durum için sınırlılıklar kapsamında bir düzenleme yapılamamıştır.

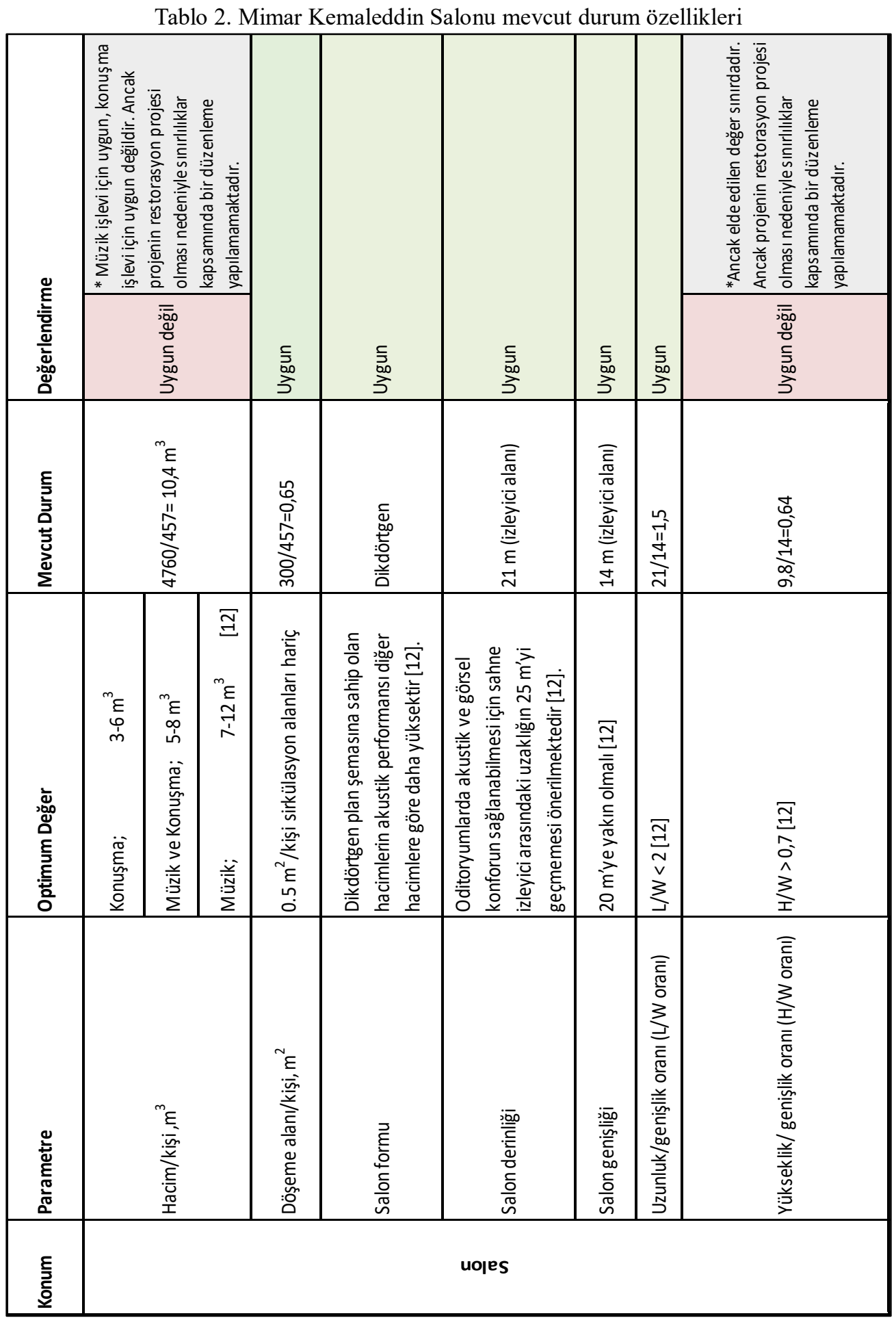


Tablo 3. Mimar Kemaleddin Salonu mevcut durum özellikleri

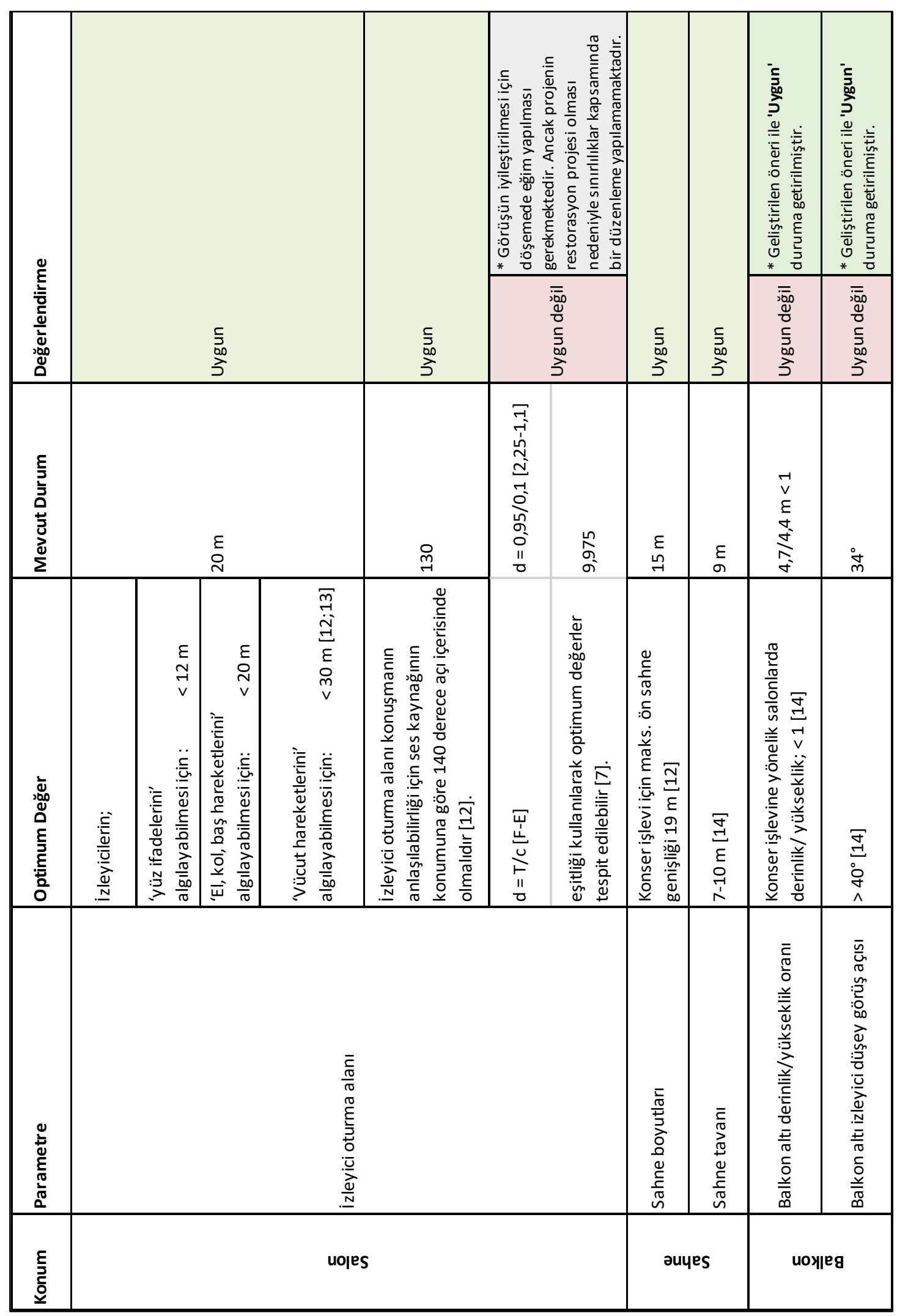




\subsection{Işın Analizleri-Mevcut Durum}

Işın analizleri için sahnede üç adet kaynak kabul edilerek yapılmıştır. Plan ve kesit ölçeğinde incelemeler yapılmıştır. Performans mekanlarında tüm seyircilere ilk yansıyan ses ulaşmalı ve hacim içerisinde homojen olarak dağılmış olması gerekmektedir.

Tablo 1. Kullanılan kaynaklar ve konumları

\begin{tabular}{|c|l|}
\hline S1 & Sahnenin orta aksında sahne ucundan 1,75 m içerde ve 1,5 m yükseklikte konumlanmaktadır. \\
\hline S2 & $\begin{array}{l}\text { Sahnenin orta aksında sahne arka duvarından } 1,30 \mathrm{~m} \text { önde ve 1,5 } \mathrm{m} \text { yükseklikte } \\
\text { konumlanmaktadır. }\end{array}$ \\
\hline S3 & $\begin{array}{l}\text { Sahnenin orta aksından } 3 \mathrm{~m} \text {, sahne duvarına } 1,1 \mathrm{~m} \text { uzaklıkta, sahne arka duvarından } 1,30 \mathrm{~m} \\
\text { önde ve 1,5 m yükseklikte konumlanmaktadır. }\end{array}$ \\
\hline
\end{tabular}

\subsubsection{Direk ses alma}

Görüş açısından incelendiğinde S1 ve S2 kaynaklarına göre Şekil 3’te incelenmiştir. Seyirci alanın düz olması nedeniyle görüş durumunu etkilemektedir. Balkonlarda görüş sıkıntısı yaşanmamaktadır. Zemin katta bulunan salonun arka sıraların görüşünü iyileştirmek için sahne yüksekliği arttırabilir, ancak bu seçenek de yeterli olmayacaktır. Projenin restorasyon projesi olması nedeniyle optimum iyileştirmelere yönelik kararlar alınacaktır.
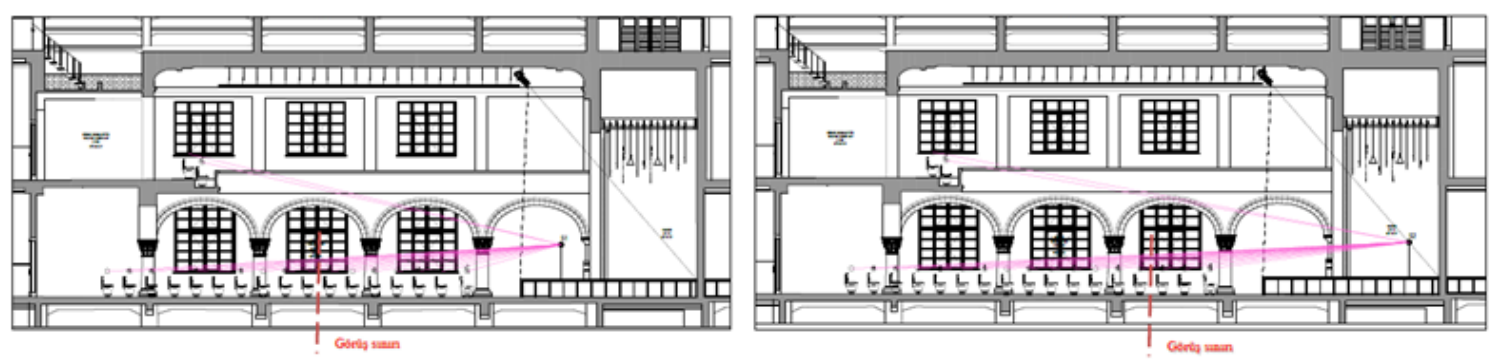

Şekil 3. S1 ve S2 kaynağ1 görüş analiz

\subsubsection{Yüzeylerden Yansiyan Sesin Analizi}

Şekil 4’te görüldüğü üzere yansıyan sesin büyük kısmı arka duvardan sağlanmaktadır. Ancak sahne arka duvarı yansıtıcı olarak değerlendirmek uygun olmayacaktır. Yanal yansımaları sağlayacak herhangi bir duvar yüzeyi yoktur; geliştirilecek öneride yanal yansımaları sağlayacak öneriler geliştirilecektir. Genellikle sahne arka duvarı; yutucu veya saçıcı olarak seçilmesi önerilmektedir [12]. Ayrıca seyirci alanı kolonlarla sınırlandırılmıştır, kolonlar dairesel oluşlarıyla sesin saçılmasına olanak sağlayacaktır. Ancak kolonların arkasında bulunan koridorlar hacmin büyütmekte ve reverberasyon süresini yükseltmektedir.

Kesitte tavan yüzeyleri için yansıma durumları incelendiğinde S1 için seyirci alanının son sırasında akustik gölge oluşmaktadır (Şekil 5). Bu durum için, son sıranın kaldırılması veya yeni yansıtıcı tavan düzenlemeleri önerilmektedir. Geliştirilecek olan çözüm önerisinde akustik gölge sorunu çözülecektir. S2 kaynağı için yansıyan ses alanı incelendiğinde bazı seyirci sıraları için ses alanı taranamamıştır (Şekil 5). Yeni geliştirilecek öneride tüm seyirci alanını tarayacak ses yansıtıcı yüzeyler geliştirilecektir. 

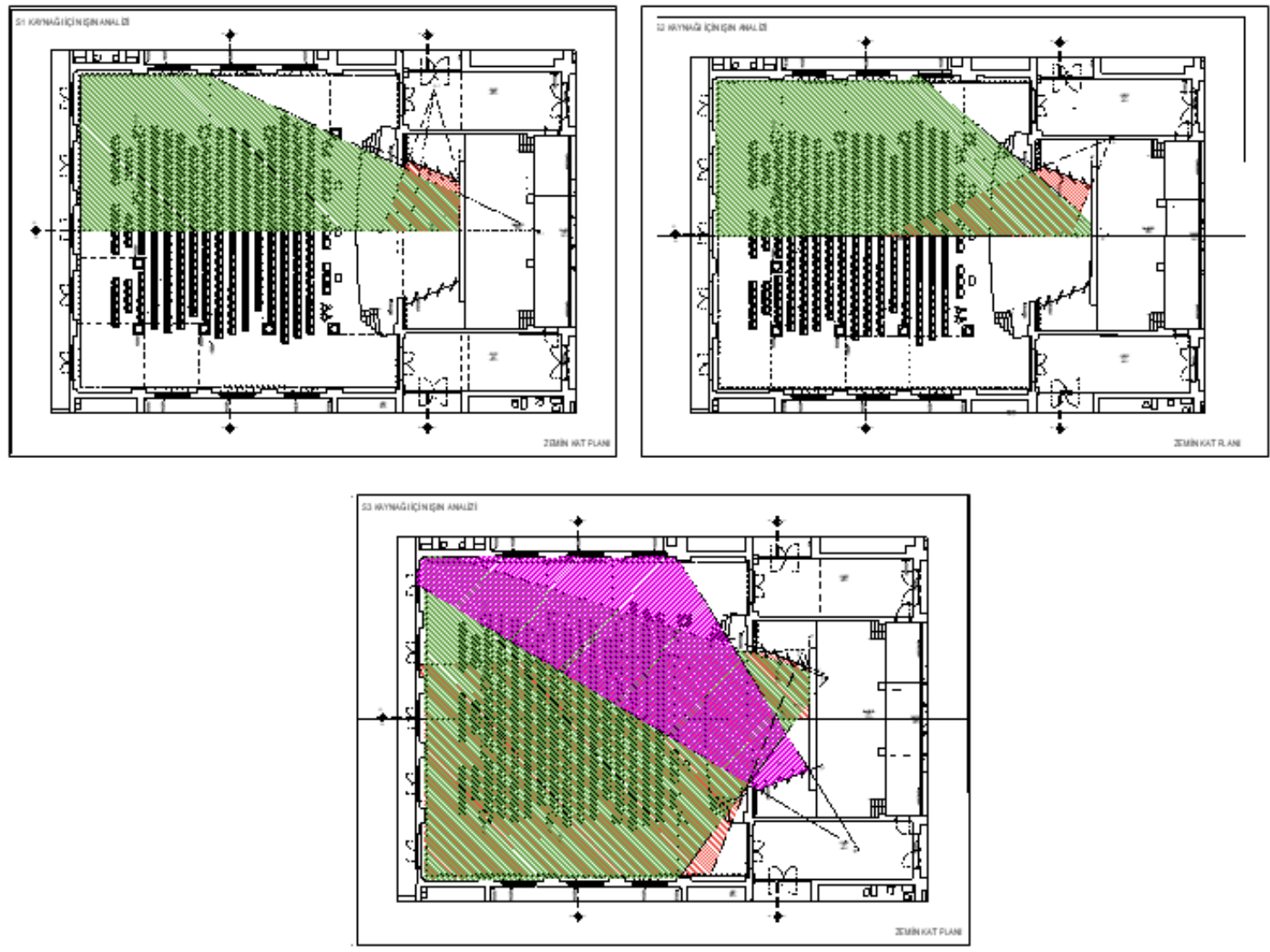

Şekil 4. S1, S2 ve S3 kaynağı için zemin kat duvar yansımaları
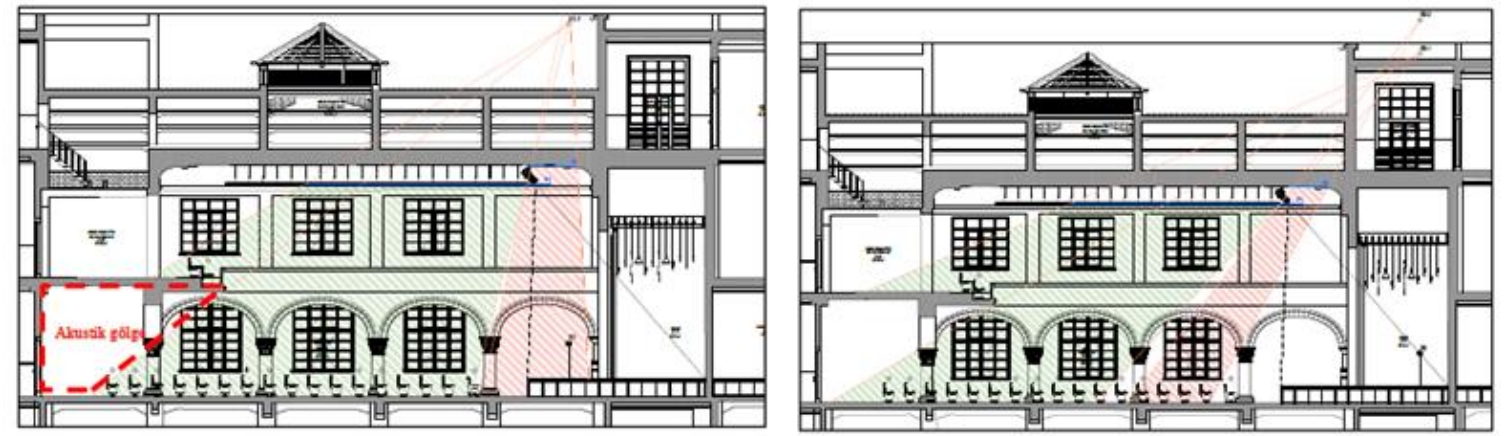

Şekil 5. S1 ve S2 kaynağı için tavan yansımaları

\subsubsection{Zaman Fark1}

Yankı, açıkça duyulabilen ve tanımlanabilen ayrı ses yansımalarıdır ve üretilen sesleri işitme mekanizmamızın sınırlı olmasından kaynaklanan bir akustik kusurdur. İki sesin kulağa ulaşma süreleri arasındaki fark 60 ms' den az ise, iki sesin birleşimini tek ses gibi duyulurken, bu fark 60 ms' i aştığında iki ayrı ses duyulmaktadır. Bu iki ses tek bir kaynaktan çıkıyor ise, yankı olarak adlandırılan bu etki (özellikle fark 100 ms’ den büyük ise) konuşmanın anlaşılmasını zorlaştırmaktadır. Bu tür gecikmeler, kişi; biri kaynaktan, diğeri yansıtıcı yüzeyden gelen iki ayrı ses duyduğunda meydana gelmektedir. Bir hacimde tüm yüzeylerden gelen birçok yansıma ise reverberasyon olarak bilinen ses olayını meydana getirerek sese farklı ve müzikte istenen bir etki katmaktadır [14,16;17].

Hedeflenen yol farkı 7m olup 20 ms'den küçük 10-20 ms aralığında olması beklenmektedir. Ancak 20$30 \mathrm{~ms}$ değerleri de kabul edilebilir aralıktır [12]. Salon için ilk ve yansımış ses arasındaki mesafeler ve süreler incelendiğinde Şekil 6'da görüldüğü üzere esas problemli olan noktaların ön sıralarda olduğu açıkça görülmektedir (S1 için: ilk sıra; 31,7 ms; orta sıra; 21 ms; arka sıra; 14 ms). Bu nedenle ön sıralar için yansımış sesin yolunu kısaltacak çözümlere gidilmesi gerekmektedir. 

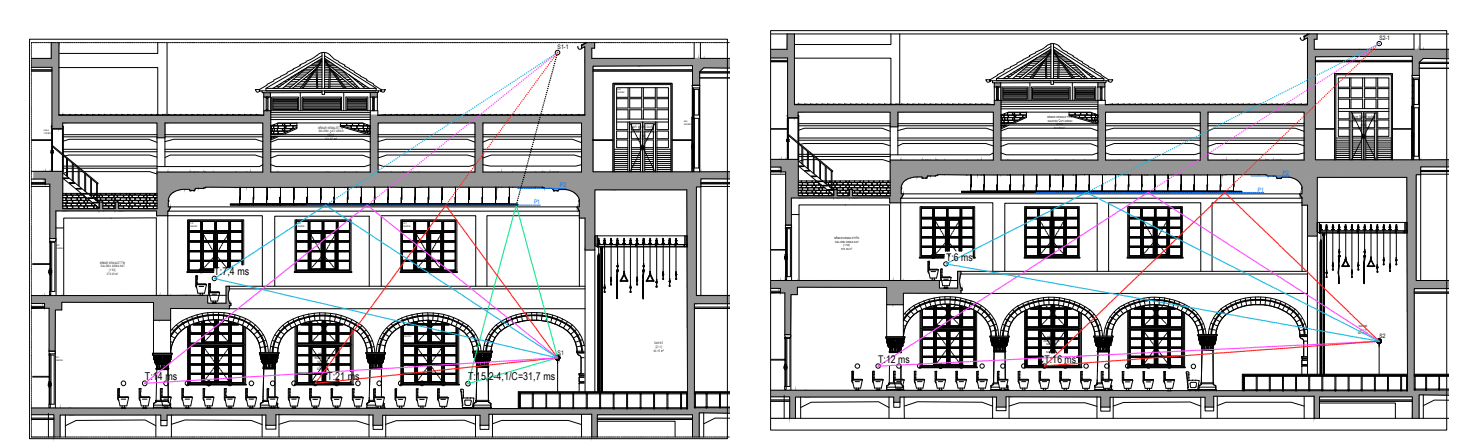

Şekil 6. S1 ve S2 kaynağı için alıcıların yol fark1

\subsubsection{Genel Değerlendirme}

Tablo 2. İncelemeler doğrultusunda yapılan problem analizi ve çözüm önerileri

\begin{tabular}{|l|l|l|}
\hline Problem & Problem Durumu & Çözüm \\
\hline Problem 1 & Akustik Gölge & Seyirci alanının son sırası kaldırılacaktır. \\
\hline Problem 2 & Görüş & Sınırlılıklar nedeniyle düzenleme yapılamayacaktır. \\
\hline Problem 3 & $\begin{array}{l}\text { Işın analizinde ses alanı tüm } \\
\text { seyirci alanını taramamaktadır }\end{array}$ & $\begin{array}{l}\text { Yansıtıcı yüzey düzenlemeleri ile çözüm } \\
\text { geliştirilecektir. }\end{array}$ \\
\hline Problem 4 & Yol fark1 & $\begin{array}{l}\text { Sahne yakınında yansıtıcı çözümleri ile yol fark1 } \\
\text { optimum değerlere ulaştırılacaktır. }\end{array}$ \\
\hline Problem 5 & Hacim & $\begin{array}{l}\text { Konferans ve konser işlevi için değişken hacim } \\
\text { oluşturulmalıdır. }\end{array}$ \\
\hline
\end{tabular}

Tablo 5 'te yapılan değerlendirmeler sonucunda mimari proje üzerinde yapılan değişiklikler sırasıyla;

- Seyirci alanının son sırası kaldırılmıştır.

- Sahnede portal ağzında ses yansıtıcı saçıcı kanopi tasarlanmıştır.

- Tavanda ses yansıtıcı-saçıcı özellikte dış bükey asma tavan yüzeyleri oluşturulmuştur.

- Değişken hacim oluşturmak için sahne yan duvarları hareketli yansıtıcı paneller yerleştirilmiştir.

- Yüzey bitiş malzemelerinde düzenlemeler yapılmıştır.

\subsection{Işın Analizleri-Öneri}

\subsubsection{Yüzeylerden Yansıyan Sesin Analizi-Öneri}

Yansıyan ses ve doğrudan iletilen ses arasındaki zaman farkının optimum değerlere getirilmesi için özellikle seyirci alanının ön taraflarında karşılaşılan sorunun çözümü amacı ile sahne açıklığının etrafına kanopi işlevi gören bir ses yansıtıcı-saçıcı özellikte dış bükey panel yerleştirilmiştir.

Tavan yansımaları incelendiğinde; her ne kadar S1 kaynağı için tavan yüzeyi ile tüm seyirci alanı taransa da S2 kaynağı için aynı durum söz konusu değildir. Bu nedenle tavan tasarımında sesin seyirci alanını tamamen taraması için dışbükey yansıtıcı paneller öngörülmüştür. Bu paneller ile hacim içerisinde birinci derece yansımalarla tüm seyirci alanı taranırken, ikinci yansımalarla orta alan-arkası ve üçüncü derece yansımalarla seyirci alanının arka kısmı taranarak dengeli ses alanı hedeflenmektedir. 

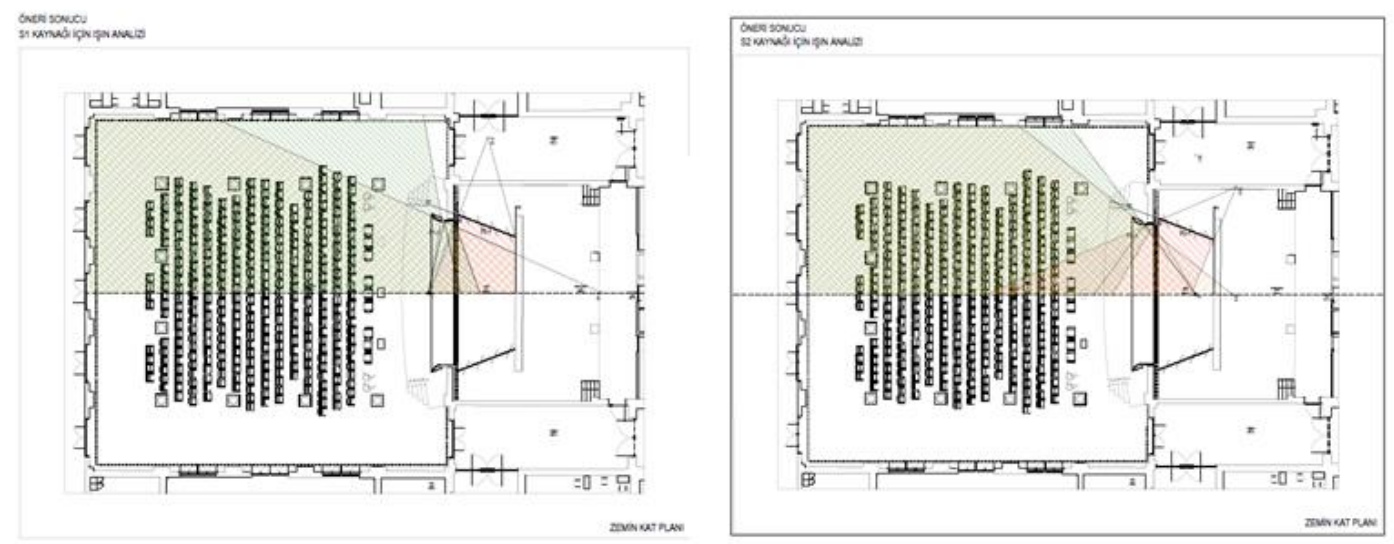

Şekil 7. S1 ve S2 kaynağı için zemin kat duvar yansımaları (öneri sonrası)
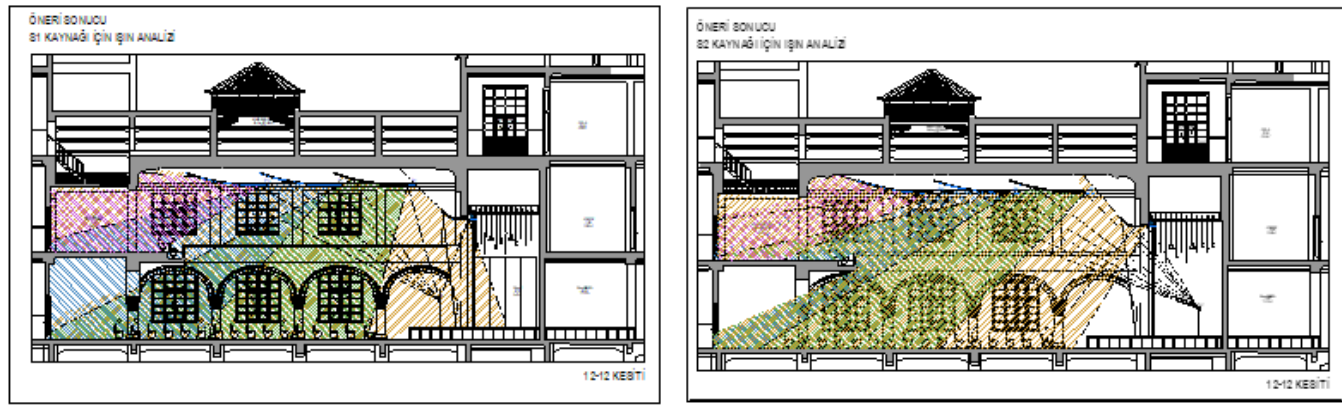

Şekil 8. S1 ve S2 kaynağı için tavan yansımaları (öneri sonrası)

Zaman farkı açısından değerlendirildiğinde öneri sonucunda; S1 için ön sırada $31 \mathrm{~ms}$ olan yol farkı geliştirilen öneri ile 23 ms'ye kadar düşürülmüştür ve bu değer kabul edilebilir değerler arasındadır. Öneri öncesi hedeflenen yol farklarından yüksek olan değerler, düşürülerek tüm alıcı noktalarında hedeflenen-kabul edilen aralıkta yer almaları sağlanmıştır (Şekil 9). S1 kaynağı için zeminde üç adet ve balkonda bir adet alıcı üzerinde zaman farkı değerlendirmeleri yapıldığında sırası ile birinci alıcıda 23 ms; ikinci alıcıda 19,4; üçüncü alıcıda 15 ve balkondaki alıcıda 14,1 ms olarak tespit edilmiştir. S2 için ise izleyici alanının ön sıralara tavan yansımaları ulaşmamaktaydı; kullanılan kanopi ile yansımalar sağlanarak, tüm alıcılarda hedeflenen yol farkları elde edilmiştir (Şekil 9). S2 kaynağı için zeminde üç adet ve balkonda bir adet alıcı üzerinde zaman farkı değerlendirmeleri yapıldığında sırası ile birinci alıcıda $14,1 \mathrm{~ms}$; ikinci alıcıda 10,2; üçüncü alıcıda 8,8 ve balkondaki alıcıda 5,2 ms olarak tespit edilmiştir.
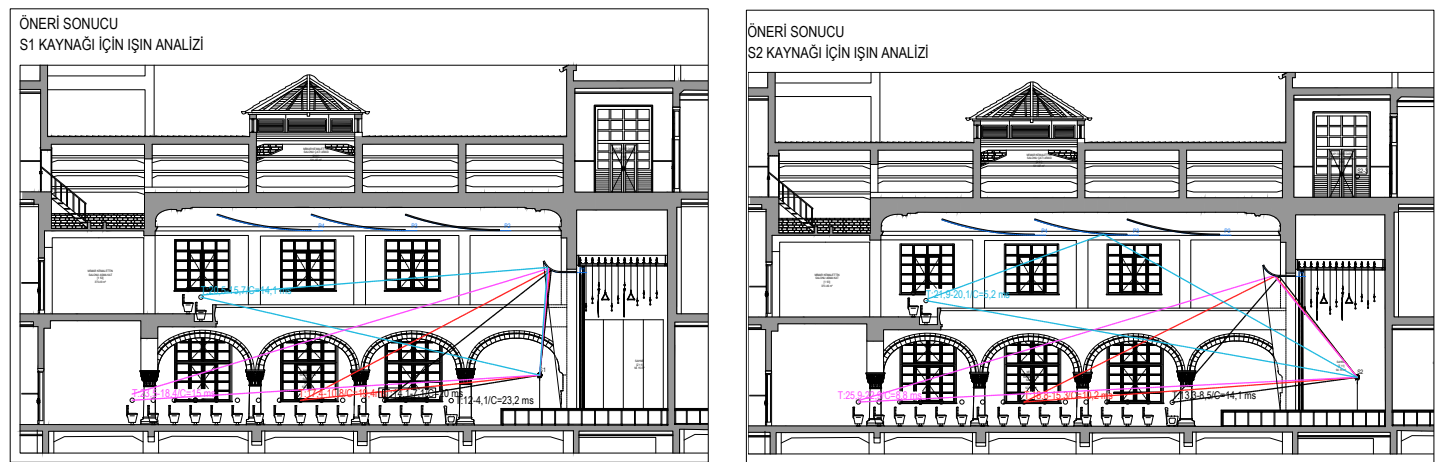

Şekil 9. S1 ve S2 kaynağı için alıcı noktalarında yol farkı (öneri sonrası) 


\section{Mimar Kemaleddin Salonu İşlevlerine Yönelik Simülasyon ile Değerlendirilmesi}

Gazi Üniversitesi Rektörlük Binası Mimar Kemaleddin Salonu; 439 kişilik izleyici kapasitesine sahip olup içerisinde konferans ve konser işlevlerini barındırmaktadır. Farklı işlevlere yönelik olarak, ihtiyaç duyulan akustik koşulların, aynı hacim içerisinde sağlanması amacıyla geliştirilen önerilerin birbirleri ile entegre edilmesiyle tasarlanmış olan, Gazi Üniversitesi Rektörlük Binası Mimar Kemaleddin Salonu'nda;

- $\quad$ sahnede oluşturulan Birleşen Hacimler Sisteminin (Coupled Volumes System) konser işlevinde,

- $\quad$ perde sisteminin (acoustical curtains) konferans işlevinde ihtiyaç duyulan akustik koşulların sağlanmasında etkili olacağı öngörülmüştür.

Tablo 3. Konferans ve konser işlevi için salonun kullanımı

\begin{tabular}{|c|c|c|}
\hline İşlevler & $\begin{array}{c}\text { Birleşen Hacimler Sistemi } \\
\text { (Coupled Volumes System) }\end{array}$ & $\begin{array}{c}\text { Akustik Perde Sistemi } \\
\text { (Acoustical Curtains) }\end{array}$ \\
\hline $\begin{array}{c}\text { Konferans } \\
\text { İşlevi }\end{array}$ & $\begin{array}{c}\text { Kapali } \\
\text { (Arka Sahne) }\end{array}$ & $\begin{array}{c}\text { Var } \\
\text { (Üst Katta Ve Alt Katta) }\end{array}$ \\
\hline $\begin{array}{c}\text { Konser } \\
\text { İşlevi }\end{array}$ & $\begin{array}{c}\text { Açik } \\
\text { (Arka Sahne) }\end{array}$ & Yok \\
\hline
\end{tabular}

Gazi Üniversitesi Rektörlük Binası Mimar Kemaleddin Salonu'nda; farklı işlevler ve farklı salon kullanımı, hacim akustiği parametrelerinin de farklı olmasını gerektirmektedir. Değişsen akustik koşullar, mimari uygulama projesi üzerinde geliştirilen akustik tasarımlar ile sağlanarak, planlanan işlevlere yönelik (konferans ve konser) optimum akustik konfor koşulları elde edilmiş̧ir. Hacim akustiğine yönelik analizler ile hedeflenen;

- Mekânın işlevi için ihtiyaç duyulan reverberasyon süresinin sağlanması,

- Mekân içerisinde konuşmanın anlaşllabilirliğinin yükseltilmesi ve

- Yank1 (eko) gibi önemli akustik problemlerin önlenmesidir.

Bu hedefler doğrultusunda; mimari uygulama projesindeki salon formu ve hacmi korunup, kullanılan malzemeler ve uygulanacak yüzeyler belirlenerek, analizleri ve değerlendirmeleri yapılmıştır.

Genel olarak;

- Sahne portali çevresine ve salonun tavanında; homojen ses alanını sağlamak amacı ile ses yansıtıcı ve konkav yüzeyler, birlikte kullanılmıştır.

- Yüksek olan reverberasyon süresini azaltmak için tavanlarda akustik sıva sistemi kullanılmıştır.

- Seyirci alanının, balkon altında kalan son sırası kaldırılmıştır.

- Konferans işlevi sırasında, sahne arka duvarı yankı veya ekoyu engellemek için yutucu özellikte perde kullanılmıştır. Salon arka koridorunun tavanı geç gelen yansımalara engel olmak üzere ses yutucu yüzeylerden oluşturulmuştur.

- Konferans anında kapı ve pencere önlerindeki perdeler aktif konumda kullanılmıştır.

\section{Hacim Akustiği Parametrelerine Yönelik Performans Kriterleri}

Amaç; konuşma ve müzik seslerinin dinleyicilere doğal yoldan, niteliği değişmeksizin erişimini sağlamaktır. Salonun mimari özellikleri ile nesnel akustik parametreler optimum aralıkta tutularak hacimde istenilen akustik performans elde edilebilir.

Gazi Üniversitesi Rektörlük Binası Restorasyon Projesi Mimar Kemaleddin Salonu, hacim içerisinde sağlanması gereken akustik konfor düzeyinin analizleri ve değerlendirmesi; aşağıda özetlenmekte olan akustik parametreler doğrultusunda yapılmıştır.
- $\mathrm{T} 30$
: Reverberasyon süresi (sn)
(Reverberation Time)
- $\quad$ EDT
: Erken sönümlenme süresi (sn)
(Early Decay Time)

51 I P a g e 


$\begin{array}{lll}\text { - STI } & \begin{array}{l}\text { Konuşmanın iletim indeksi (Konuşmanın anlaşılabilirliği) } \\ \text { (Speech Transmission Index) }\end{array} \\ \text { D } & \text { Konuşmanın belirginliği } \\ & \text { (Definition) } \\ & \text { Sesin Berraklı̆̆1 veya Netliği } \\ & \text { (Clarity) } \\ \text { C80 } & \text { Ses basıç seviyesi farkı (dBA) } \\ & \text { (Sound Pressure Level) }\end{array}$

Tablo 7’te proje kapsamında değerlendirilecek nesnel akustik parametrelerin; konuşma ve müzik işlevine dair optimum değerleri verilmiştir. Reverberasyon süresi, akustik parametrelerden en belirleyici ve baskın olan parametredir. Reverberasyon süresine dair verilen optimum değerlerin dışında Şekil 10'da salonda yer verilen işleve göre $500 \mathrm{~Hz}$ 'de optimum değerler verilmiştir. Hacimle ilişkili olarak konferans ve konser işlevlerinde verilen reverberasyon süreleri sırasıyla; 0,8 ve 1,6 sn'dir. Bu değerler için $\% 20$ lik tolerans arağı ise konferans için $0,64-0,96$; konser için 1,28-1,92 sn'dir [8,9].

Tablo 7. Performans salonlarında nesnel akustik parametreler

\begin{tabular}{|c|c|c|c|c|}
\hline Parametre & Özellik & $\begin{array}{l}\text { Hissedilen } \\
\text { Fark }\end{array}$ & Konuşma İşlevi & Müzik İşlevi \\
\hline $\begin{array}{l}\text { Reverberasyon Süresi, sn } \\
\text { (Reverberation Time) (T 30) } \\
\text { [7] }\end{array}$ & $\begin{array}{l}\text { Geç, yansımalar } \text { (Direkt } \\
\text { sesten } 50 \mathrm{~ms} \text { den geç, } \\
\text { gelenler) (canlılık, açıklık, } \\
\text { parlaklık) }\end{array}$ & $\% 5$ & $(0,64-0,96 \mathrm{~s})[8,9]$ & $(1,28-1,92 \mathrm{~s})[8,9]$ \\
\hline $\begin{array}{l}\text { Erken Sönümlenme Süresi, } \\
\text { sn (Early Decay Time) (EDT) } \\
\text { [7] }\end{array}$ & $\begin{array}{l}\text { Düşme eğrisinin ilk bölümü } \\
\text { (uzun ise canlılık, kısa ise } \\
\text { açıklık) }\end{array}$ & $\% 5$ & EDT $<$ T30 & $\mathrm{EDT}<\mathrm{T} 30$ \\
\hline $\begin{array}{l}\text { Konuşmanın Belirginliği } \\
\text { (Definition) (D 50) } \\
\text { [11] }\end{array}$ & $\begin{array}{l}50 \mathrm{~ms} \text { de gelen enerjinin } \\
\text { toplam enerjiye } \\
\text { (Anlaşılabilirlik) }\end{array}$ & $\% 5$ & $0,3-0,7$ & - \\
\hline $\begin{array}{l}\text { Sesin Netliği (Clarity) (C 80) } \\
\text { [11] }\end{array}$ & $\begin{array}{l}\text { Dinleyiciye } 80 \mathrm{~ms} \text { içinde } \\
\text { gelen ses düzeyi ile toplam } \\
\text { ses düzeyi arasındaki } \\
\text { logaritmik fark (Açılık) }\end{array}$ & $1 \mathrm{~dB}$ & - & $-5 \mathrm{~dB}-+5 \mathrm{~dB}$ \\
\hline $\begin{array}{l}\text { Konuşmanın İletim İndeksi } \\
\text { (Speech Transmission } \\
\text { İndex)(STI) [10] }\end{array}$ & Konuşmanın anlaşılabilirliği & - & $\begin{array}{|lccc|}0.00 & -0.30 & \text { Kötü } \\
0.30 & -0.45 & \text { Zayıf } \\
0.45 & -0.60 & \text { Orta } \\
0.60-0.75 \text { İyi } & \\
0.75-1.00 \text { Çok iyi } \\
\end{array}$ & - \\
\hline $\begin{array}{l}\text { Ses Basınç Seviyesi Farkı, } \\
\text { dBA } \\
\text { (Sound Pressure Level) } \\
(\triangle \text { SPL(A)) }[15]\end{array}$ & $\begin{array}{l}\text { Toplam ses basıncı fark1 } \\
\text { (Ses } \\
\text { anlaş1labilirlik) }\end{array}$ & - & $\Delta \mathrm{SPL}(\mathrm{A})<10 \mathrm{dBA}$ & $\Delta \mathrm{SPL}(\mathrm{A})<10 \mathrm{dBA}$ \\
\hline
\end{tabular}




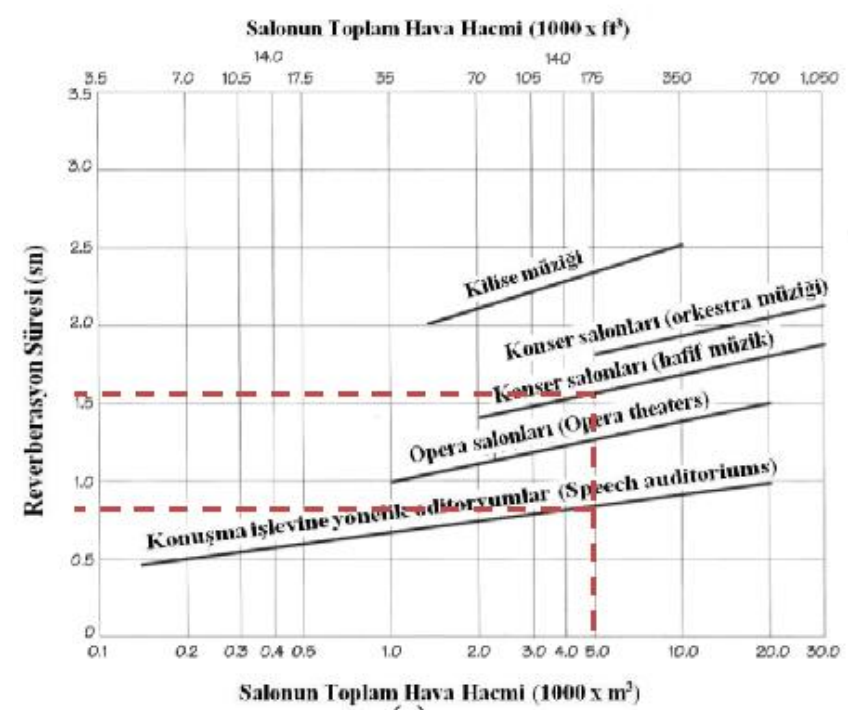

(a)
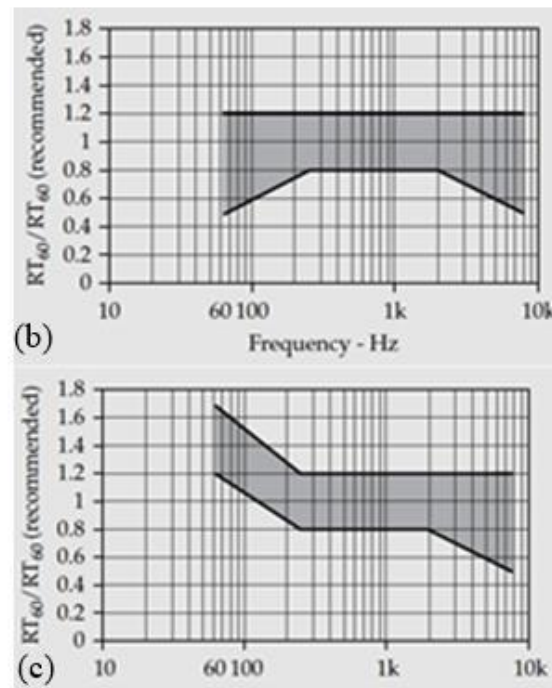

Şekil 10. Hacme göre reverberasyon süresi grafiğgi (500 Hz) (a) [7] ve \pm 20 tolerans aralığg ((b), konferans işlevi), ((c), konser işlevi) [8,9]

\subsection{Konferans İşlevi - Odeon Simülasyon Programı Analizleri ve Değerlendirilmesi}

Bu çalışma kapsamında, Gazi Üniversitesi Rektörlük Binası Mimar Kemaleddin Salonu'nda konferans işlevine yönelik ihtiyaç duyulan akustik koşulların sağlanması amacı ile;

- sahne arkasının hava hacmi nedeniyle reverberasyon süresinin yükselmemesi için, sahne yan duvarları; hareketli panellerden oluşmaktadır ve konferans anında kapalı tutulması öngörülerek akustik tasarımı yapılmıştır. Bu hareket eden paneller, bir sistem üzerinde 180 derece dönebilen ve birbirlerine bitişik olarak dizilmiş ses yansıtıcı bir yüzey olarak (Şekil 11) tasarlanmış olup, aynı yüzeylerin konser işlevinde de farklı şekilde kullanımı öngörülerek, salon tasarımı sabit tutulmuştur.

- konferans işlevi sırasında kullanılmak üzere, salonda bulunan pencere ve kapıların önünde kolonların arasını tamamen örtecek şekilde ağır kumaş perde önerilmiştir.

- ses yansitıci/saçıcı dişbükey tavan ve kanopi, konuşmacılara ait direkt sesi destekleyen ses yansımalarını sağlayacak boyut ve biçimde tasarlanmıştır.

Tablo 8. Konferans işlevi için salonun kullanımı

\begin{tabular}{|c|c|c|}
\hline İşlevler & $\begin{array}{l}\text { Birleşen Hacimler Sistemi } \\
\text { (Coupled Volumes System) }\end{array}$ & $\begin{array}{l}\text { Akustik Perde Sistemi } \\
\text { (Acoustical Curtains) }\end{array}$ \\
\hline $\begin{array}{l}\text { Konferans } \\
\text { İşlevi }\end{array}$ & $\begin{array}{c}\text { KAPALI } \\
\text { (Arka Sahne) }\end{array}$ & $\begin{array}{c}\text { VAR } \\
\text { (Üst katta ve alt katta) }\end{array}$ \\
\hline
\end{tabular}




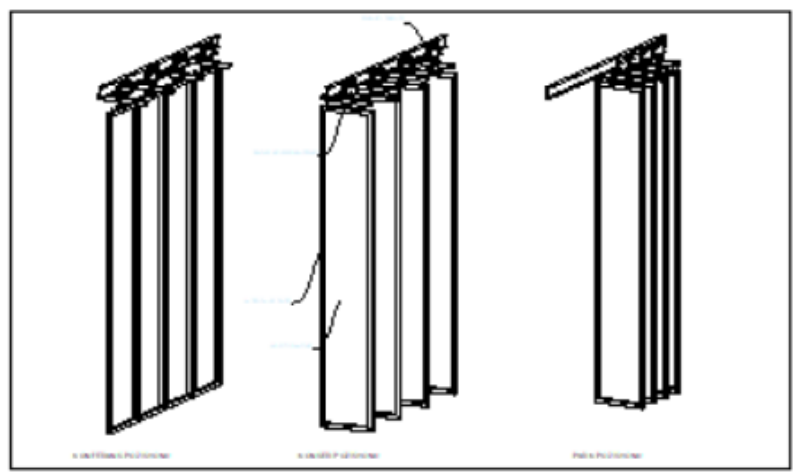

Şekil 11. Sahne yan duvarları için önerilen ahşap yansıtıcı panel
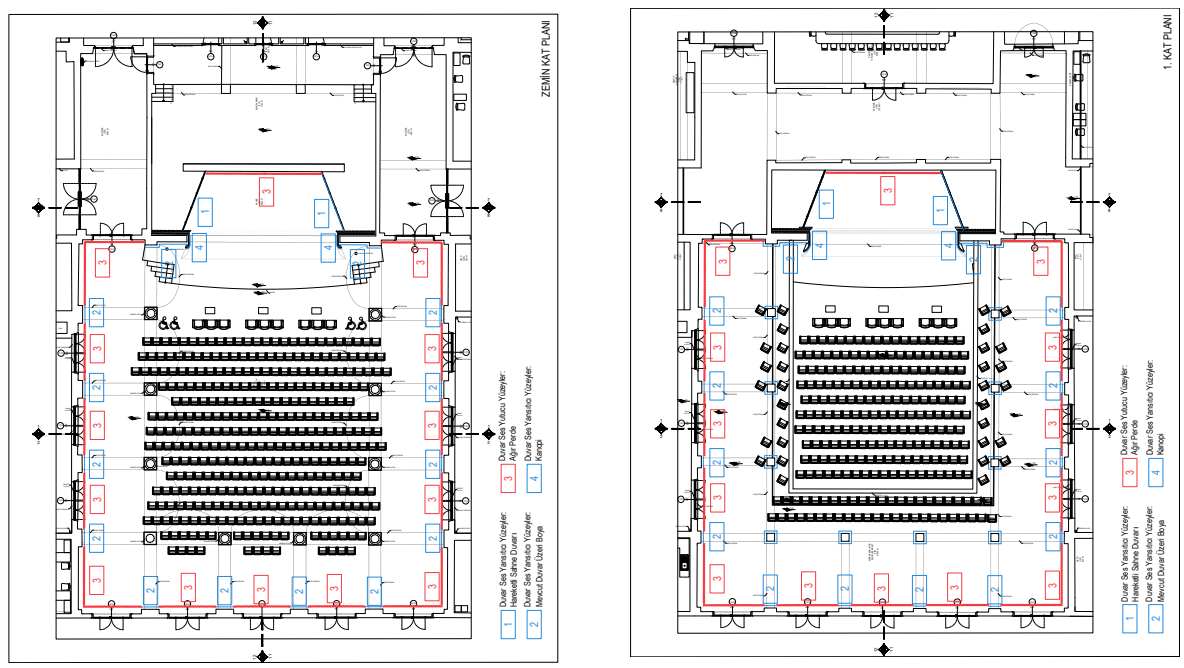

Şekil 12. Konferans işlevi için kullanılması önerilen malzemelerin yerleşimi, zemin ve 1. kat planı

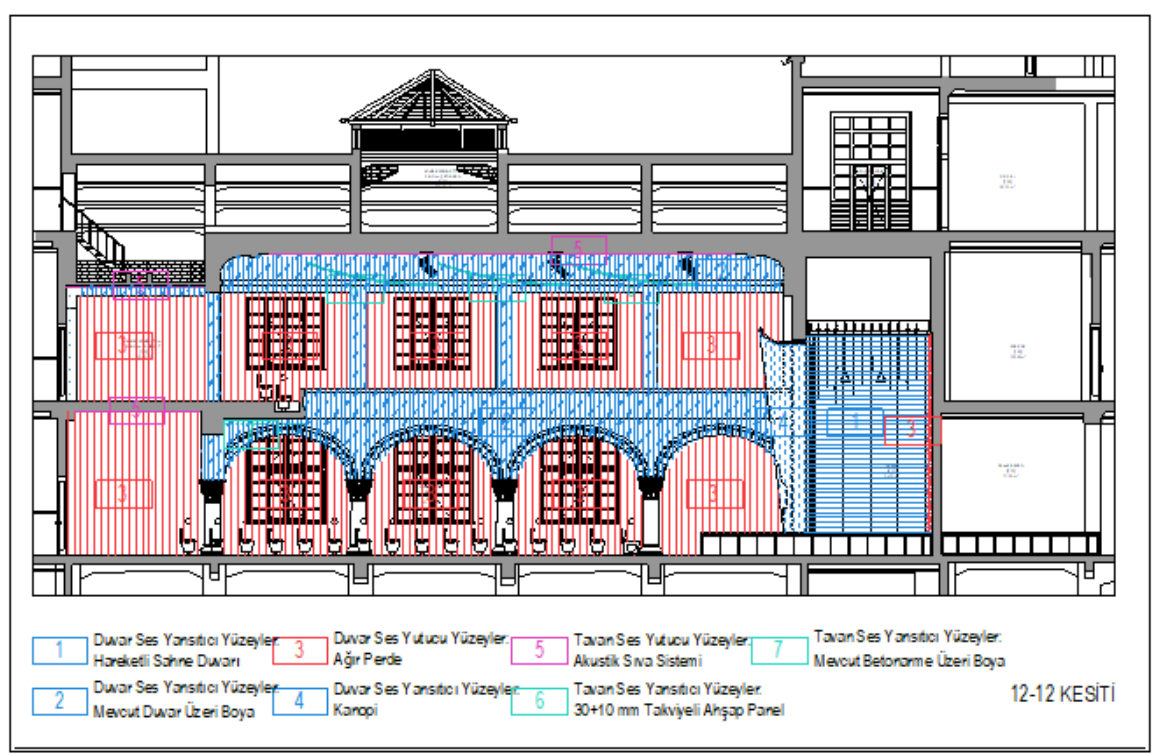

Şekil 13. Konferans işlevi için kullanılması önerilen malzemelerin yerleşimi, kesit 

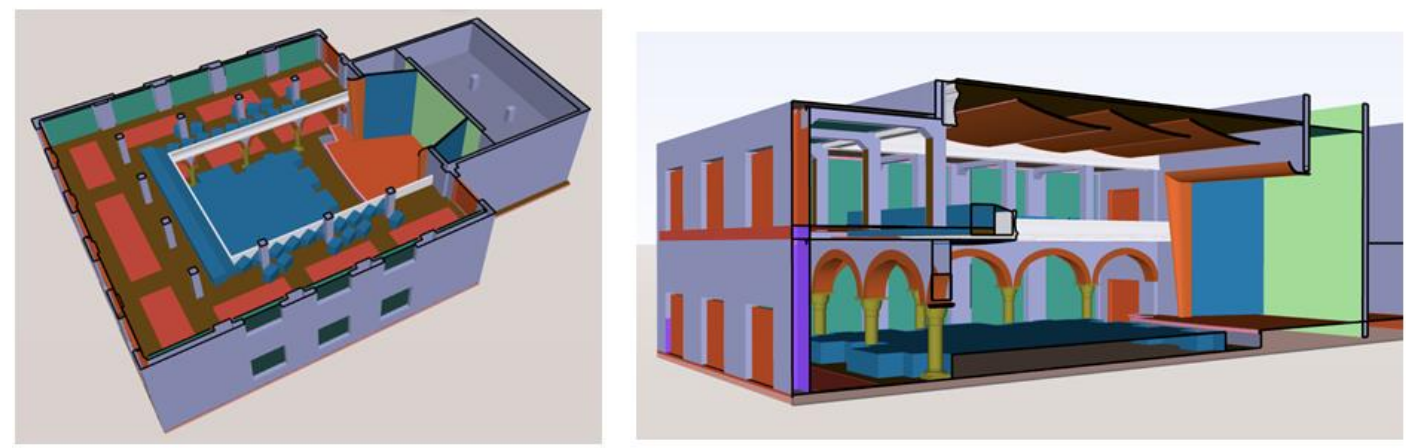

Şekil 14. Konferans işlevi 3 boyutlu görseli (Sketch-up modeli)
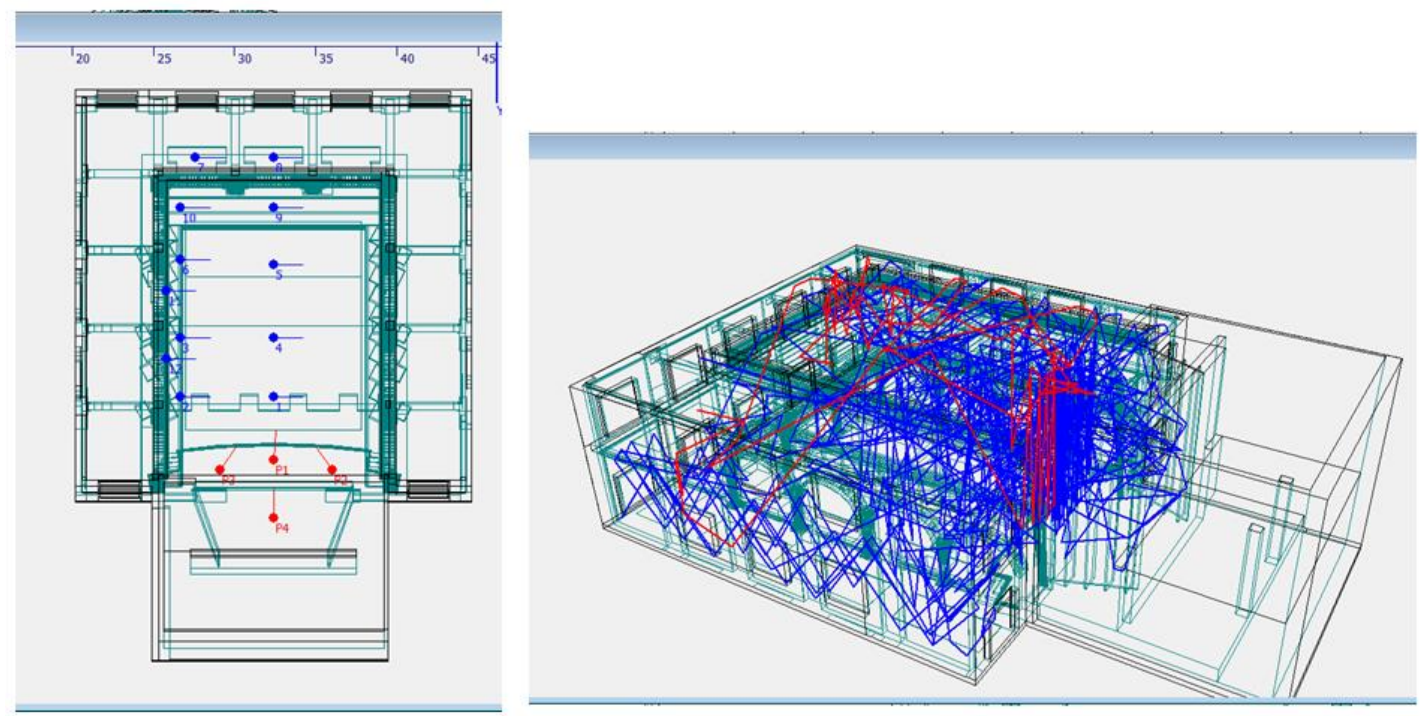

Şekil 15. Çok Amaçlı Salon- konferans işlevi kaynak-alıcı konumları ve hacim içi yansıyan seslerin ışın analizi ile ifadesi
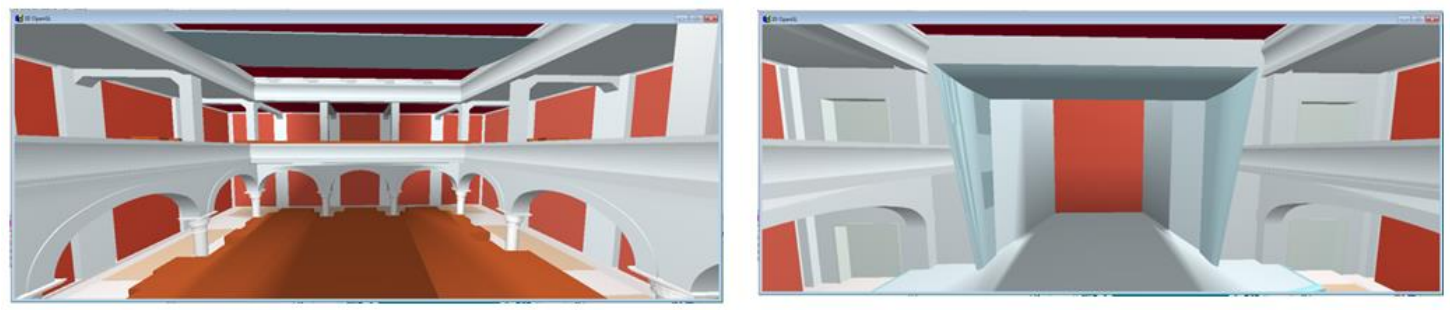

Şekil 16.

Çok Amaçlı Salon - konferans işlevi sahneden salona ve salondan sahneye bakış (Odeon modeli) 

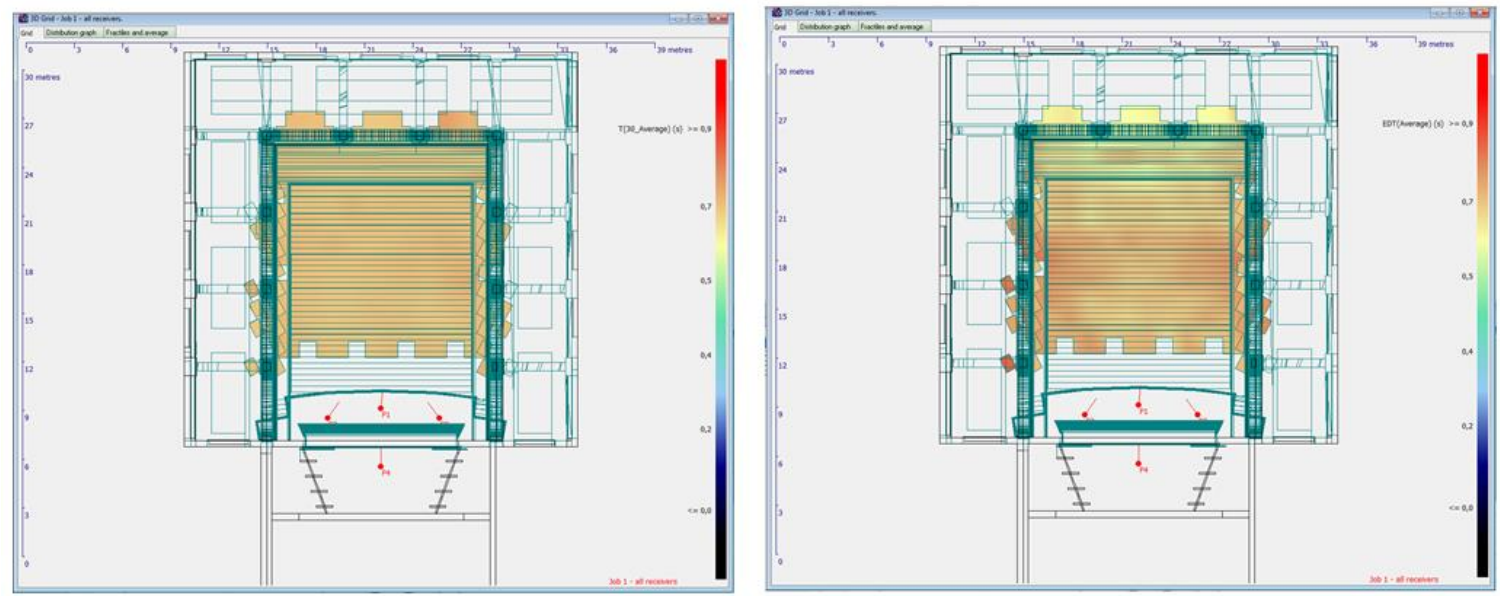

Şekil 17. Konferans işlevi için reverberasyon süresi (T30) ve erken sönümlenme süresi (EDT) parametresinin dağılımı (ortalama)
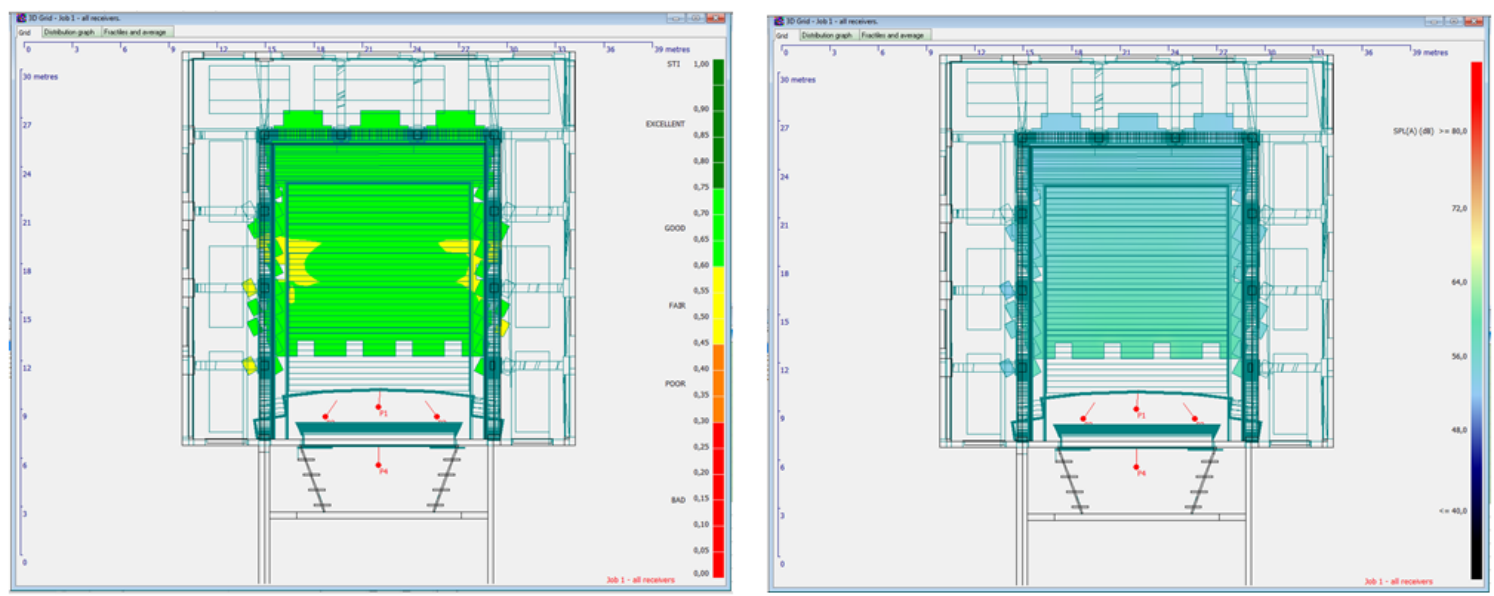

Şekil 18. Konferans işlevi için konuşmanın iletim indeksi (STI) ve ses basınç seviyesi (SPL(A)) parametresinin dağ 1 lımı

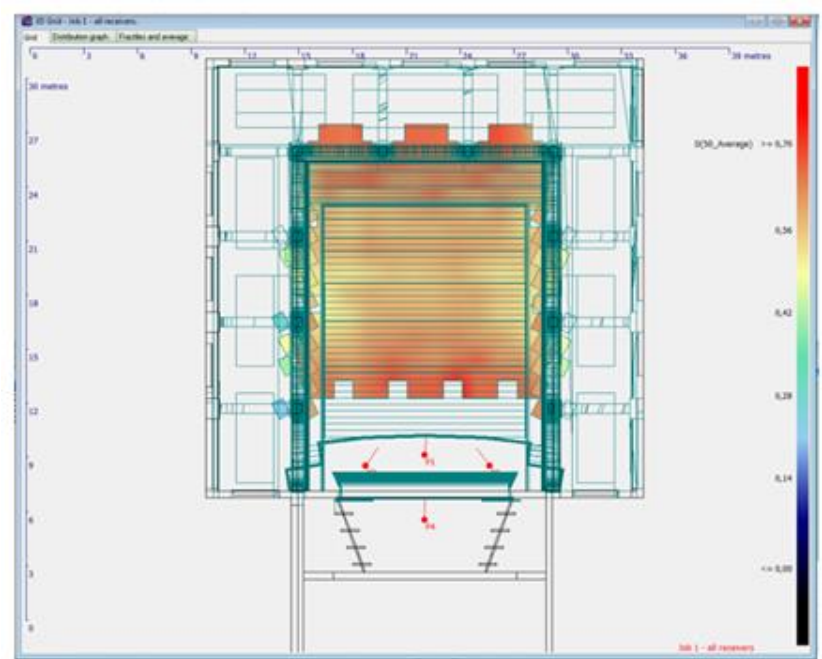

Şekil 19. Konferans işlevi için konuşmanın belirginliği (D50) parametresinin dağılımı (ortalama) 
Tablo 9. Çok Amaçlı Salon- konferans işlevi için geliştirilen önerinin hacim akustiği açısından analiz sonuçlarının değerlendirmesi

\begin{tabular}{|c|c|c|c|}
\hline $\begin{array}{ll}\text { Hacim } & \text { Akustiği } \\
\text { Parametreleri } & \end{array}$ & Optimum Değerler & $\begin{array}{l}\text { Konferans Öneri } \\
\text { Analiz Sonuçları }\end{array}$ & Değerlendirme \\
\hline $\begin{array}{l}\text { T mid Reverberasyon } \\
\text { Süresi, sn (T 30) }\end{array}$ & $0,64-0,96 \mathrm{sn}[7]$ & $0,73 \mathrm{sn}$ & $\begin{array}{c}\text { UYGUN } \\
0,64<\mathbf{0 , 7 3}<0,96\end{array}$ \\
\hline $\begin{array}{l}\text { EDT } \\
\text { Erken Sönümlenme } \\
\text { Süresi, sn }\end{array}$ & $\mathrm{EDT}<\mathrm{T} 30[7]$ & $0,72 \mathrm{sn}$ & $\begin{array}{c}\text { UYGUN } \\
\mathbf{0 , 7 2}<0,73\end{array}$ \\
\hline $\begin{array}{l}\text { D 50 } \\
\text { Konuşmanın Belirginliği }\end{array}$ & $0,3-0,7[11]$ & 0,62 & $\begin{array}{c}\text { UYGUN } \\
0,3<\mathbf{0 , 6 2}<0,7\end{array}$ \\
\hline $\begin{array}{l}\text { STI } \\
\text { Konuşmanın İletim } \\
\text { İndeksi }\end{array}$ & $\begin{array}{ll}0.00-0.30 & \text { Kötü } \\
0.30-0.45 & \text { Zayif } \\
0.45-0.60 & \text { Orta } \\
0.60-0.75 . & \text { İyi } \\
0.75-1.00 & \text { Çok iyi }[10]\end{array}$ & 0,63 & $\begin{array}{c}\text { UYGUN } \\
0,60<\mathbf{0 , 6 3}<0,75 \text { İyi }\end{array}$ \\
\hline $\begin{array}{l}\mathbf{\Delta} \text { SPL(A) } \\
\text { Ses Basınç Seviyesi } \\
\text { Fark1, dBA }\end{array}$ & $\Delta \mathrm{SPL}(\mathrm{A})<10 \mathrm{dBA}[15]$ & 7,9 & $\begin{array}{c}\text { UYGUN } \\
7,9<10 \mathrm{dBA}\end{array}$ \\
\hline
\end{tabular}

Gazi Üniversitesi Rektörlük Binası Mimar Kemaleddin Salonu mimari uygulama projesi kapsamında, konferans işlevi için ihtiyaç duyulan akustik koşulların sağlanabilmesi amacıyla hacmin duvar, döşeme ve asma tavan malzemelerini kapsayan iyileştirmelerle (Şekil 12, Şekil 13) birlikte Şekil 11 'de verilen hareketli paneller ile akustik tasarım önerisi geliştirilmiştir.

- Konferans işlevi için; sahne yan duvarları hareketli panellerle kapatılarak hacim küçültülmüş ve salon içerisinde ağır perdeler kullanılarak; ulusal/uluslararası mevzuata uygun koşullar sağlanmıştır (Tablo 9).

\subsection{Konser İşlevi - Odeon Simulasyon Programı Analizleri ve Değerlendirilmesi}

Bu çalışma kapsamında, Gazi Üniversitesi Rektörlük Binası Mimar Kemaleddin Salonu’nda konser işlevine yönelik olarak ihtiyaç duyulan akustik koşullar;

- Konferans işlevine göre daha yüksek reverberasyon süresine olan ihtiyaç; salon tasarımı sabit tutularak sahnede ise Birleşen Hacimler Sistemi (Coupled Volumes System) tasarlanması ile hava hacmi arttırılarak sağlanabilmiştir (Şekil 20, Şekil 21).

- Reverberasyon süresinin yükseltilmesi için pencere, kapı ve sahne arka duvarında kullanılan perdenin kaldırılması önerilmiștir.

Tablo 10. Konser işlevi için salonun kullanımı

\begin{tabular}{|l|c|c|}
\hline İşlevler & $\begin{array}{c}\text { Birleşen Hacimler Sistemi } \\
\text { (Coupled Volumes System) }\end{array}$ & $\begin{array}{c}\text { Akustik Perde Sistemi } \\
\text { (Acoustical Curtains) }\end{array}$ \\
\hline $\begin{array}{c}\text { Konferans } \\
\text { İşlevi }\end{array}$ & $\begin{array}{c}\text { AÇIK } \\
\text { (Arka Sahne) }\end{array}$ & YOK \\
\hline
\end{tabular}



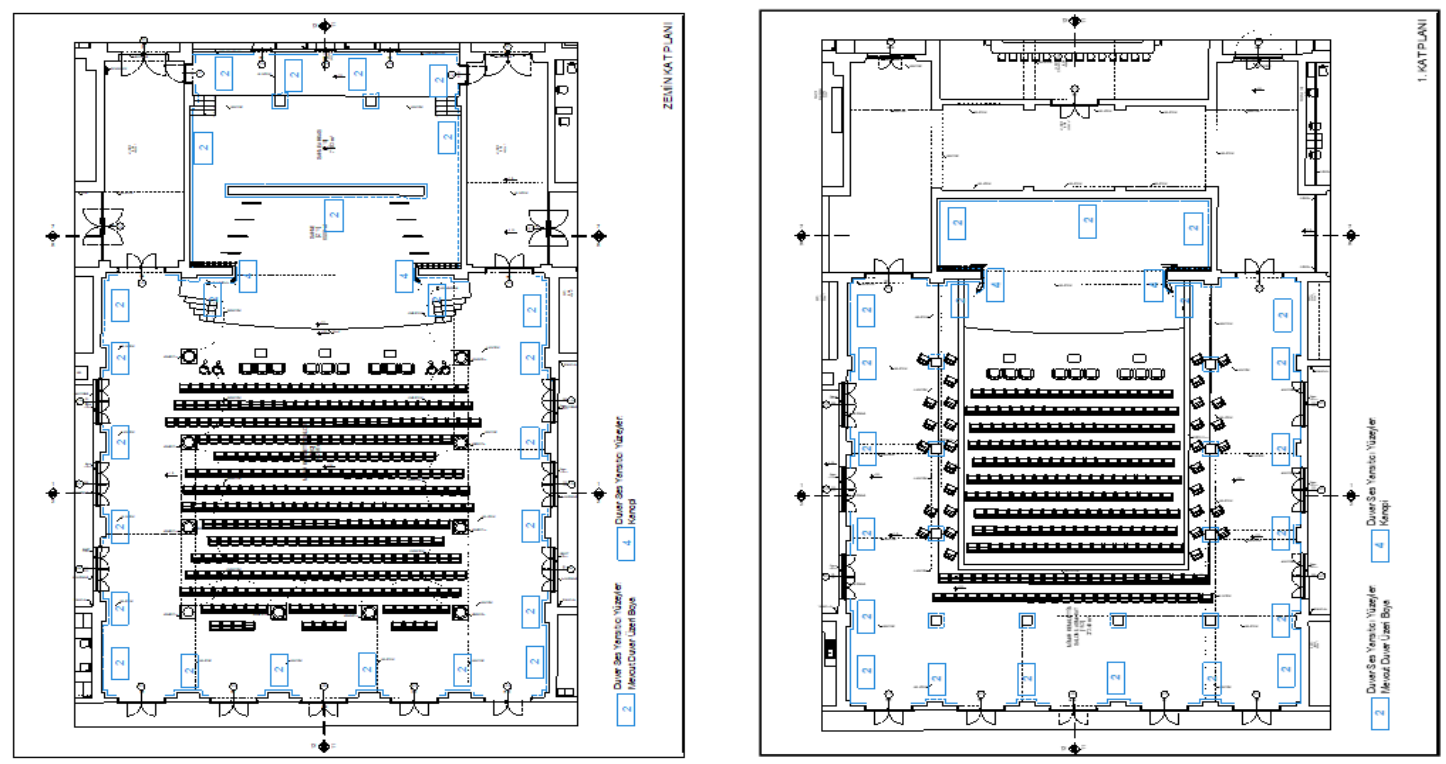

Şekil 20. Konser işlevi için kullanılması önerilen malzemelerin yerleşimi, zemin ve 1.kat planı

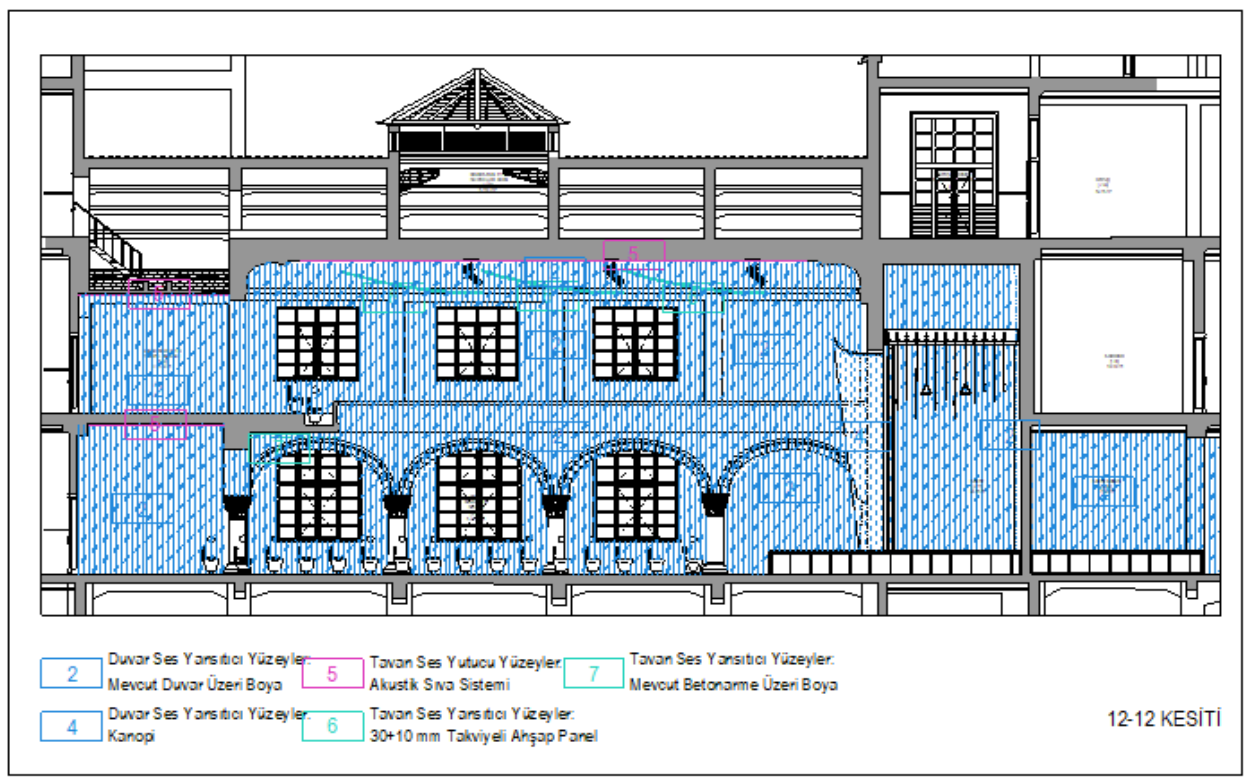

Şekil 21. Konser işlevi için kullanılması önerilen malzemelerin yerleşimi, kesit
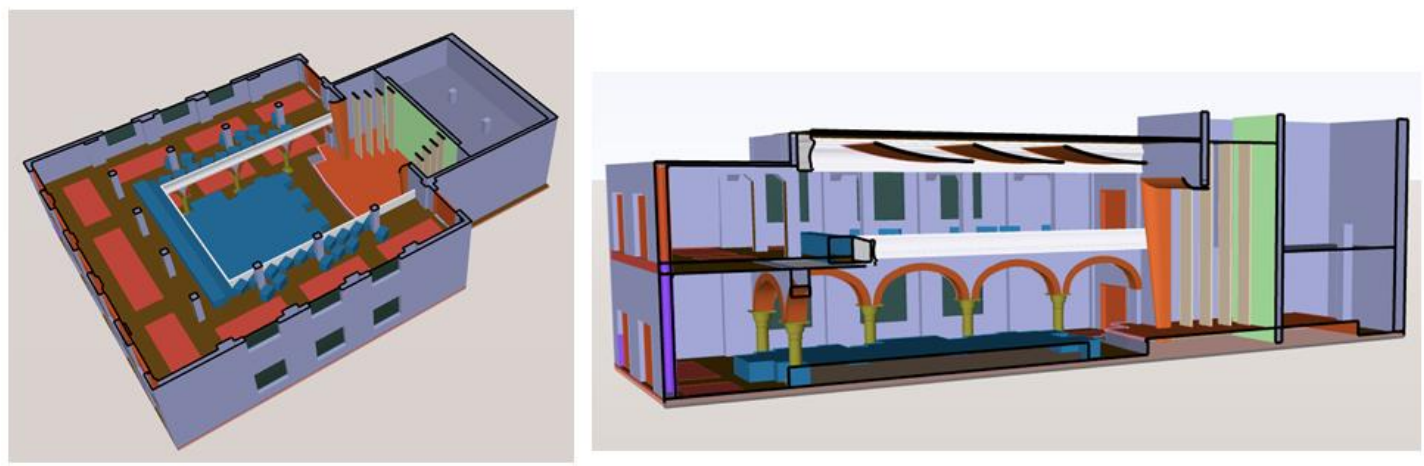

Şekil 22. Konser işlevi 3 boyutlu görseli (Sketch-up modeli) 

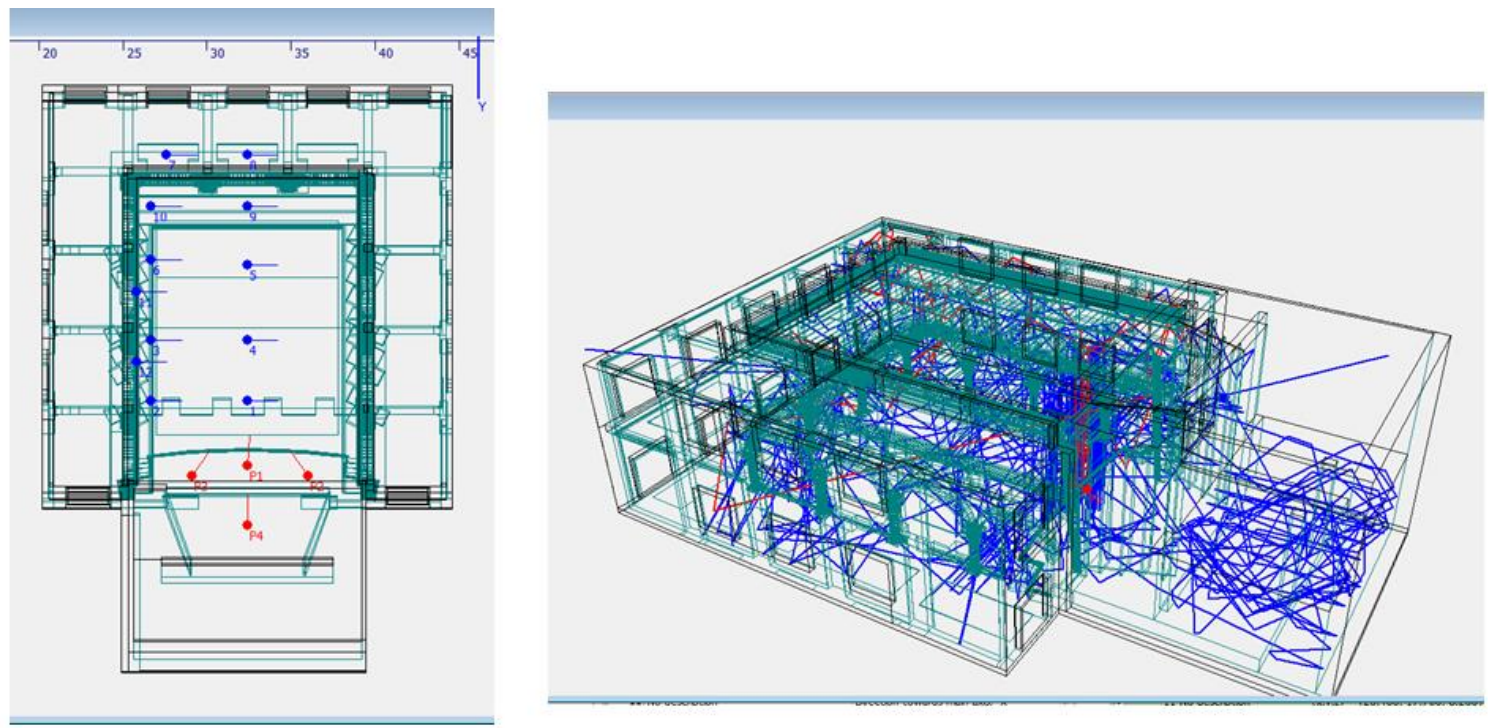

Şekil 23. Çok Amaçlı Salon- konferans işlevi kaynak-alıcı konumları ve hacim içi yansıyan seslerin ışın analizi ile ifadesi
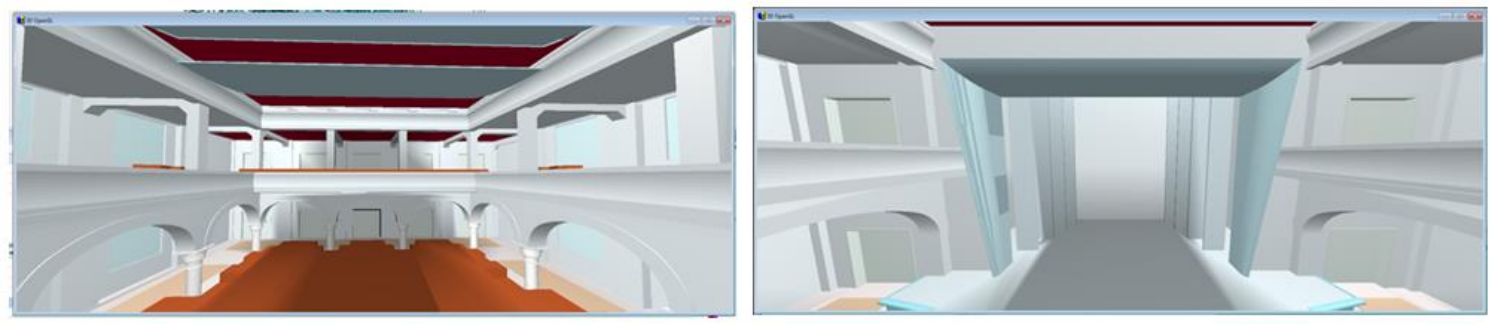

Şekil 24. Çok Amaçlı Salon - konser işlevi sahneden salona ve salondan sahneye bakış (Odeon modeli)
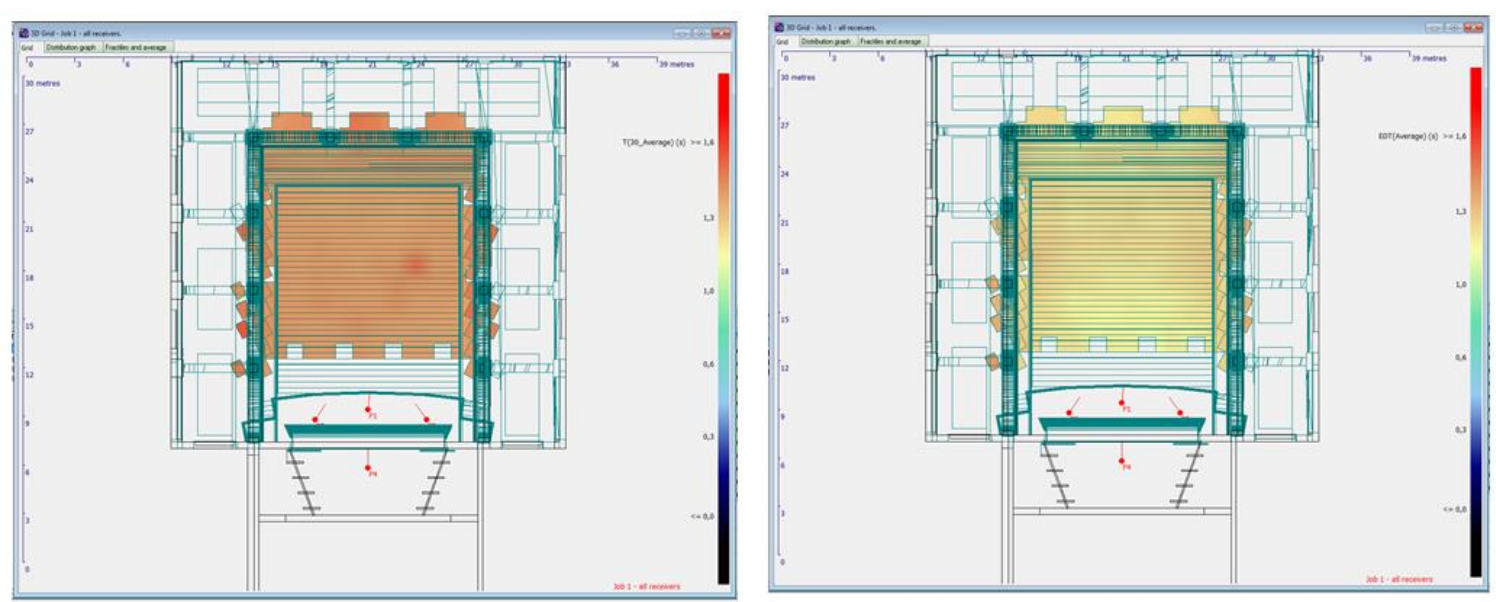

Şekil 25. Konser işlevi için reverberasyon süresi (T30) ve erken sönümlenme süresi (EDT) parametrelerinin dağ 1 lımı (ortalama) 

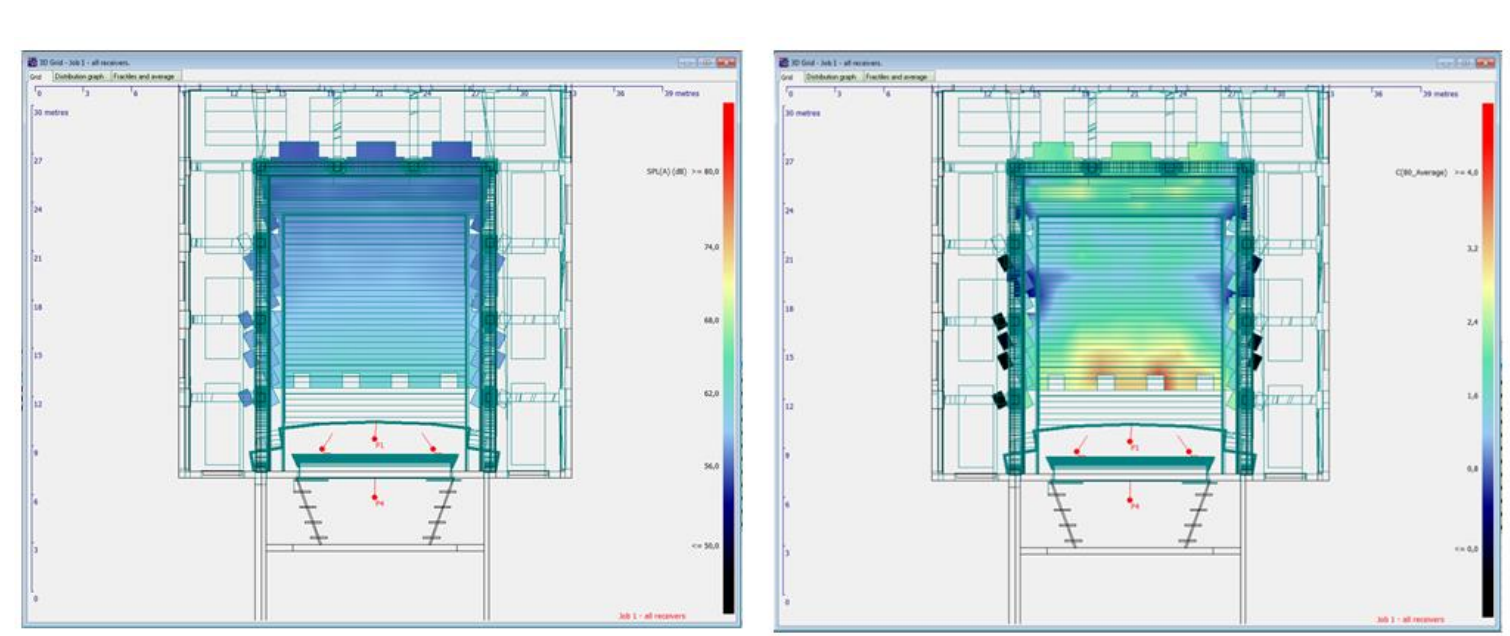

Şekil 26. Konferans işlevi için ses basınç seviyesi (SPL(A)) ve sesin berraklığı ve netliği (C80) parametresinin dağılımı

Tablo 11. Çok Amaçlı Salon- konser işlevi için geliştirilen önerinin hacim akustiği açısından analiz sonuçlarının değerlendirmesi

\begin{tabular}{|c|c|c|c|}
\hline $\begin{array}{l}\text { Hacim Akustiği } \\
\text { Parametreleri }\end{array}$ & $\begin{array}{l}\text { Optimum } \\
\text { Değerler }\end{array}$ & $\begin{array}{l}\text { Konser Öneri } \\
\text { Analiz Sonuçları }\end{array}$ & Değerlendirme \\
\hline $\begin{array}{l}\text { T mid Reverberasyon Süresi, } \\
\text { sn (T 30) }\end{array}$ & $1,28-1,92$ sn [7] & $1,43 \mathrm{sn}$ & $\begin{array}{l}\text { UYGUN } \\
1,28<\mathbf{1 , 4 3}<1,92\end{array}$ \\
\hline $\begin{array}{l}\text { EDT } \\
\text { Erken Sönümlenme Süresi, } \\
\text { sn }\end{array}$ & $\begin{array}{l}\text { EDT }<\text { T mid } \\
\text { (Birleşen hacimler } \\
\text { için) [7] }\end{array}$ & $1,23 \mathrm{sn}$ & $\begin{array}{l}\text { UYGUN } \\
\mathbf{1 , 2 3}<1,43\end{array}$ \\
\hline $\begin{array}{l}\text { C } 80 \\
\text { Sesin Berraklığ } 1 \text { ve Netliği }\end{array}$ & $-5 \mathrm{~dB}-+5 \mathrm{~dB}[11]$ & 1,95 & $\begin{array}{l}\text { UYGUN } \\
-5<1,95<+5\end{array}$ \\
\hline $\begin{array}{l}\Delta \mathbf{S P L}(\mathbf{A}) \\
\text { Ses Basınç Seviyesi Farkı, } \\
\text { dBA }\end{array}$ & $\begin{array}{l}\Delta \operatorname{SPL}(\mathrm{A})<10 \quad \mathrm{dBA} \\
{[15]}\end{array}$ & $6,3 \mathrm{dBA}$ & $\begin{array}{l}\text { UYGUN } \\
\mathbf{6 , 3}<10 \mathrm{dBA}\end{array}$ \\
\hline
\end{tabular}

Gazi Üniversitesi Rektörlük Binası Mimar Kemaleddin Salonu mimari uygulama projesi kapsamında, konser işlevi için ihtiyaç duyulan akustik koşulların sağlanabilmesi amacıyla hacmin duvar, döşeme ve asma tavan malzemelerini kapsayan iyileştirmelerle (Şekil 20, Şekil 21) birlikte Şekil 11'de verilen hareketli paneller ile konser işlevine yönelik akustik tasarım önerisi geliştirilmiştir.

- Konser işlevi için; Birleşen Hacimler Sistemi (Coupled Volumes System) ve konferans işlevinde kullanılan perdelerin kaldırılması ile ulusal/uluslararası mevzuata uygun koşullar sağlanmıştır.

\section{Sonuç}

Konferans ve konser gibi farklı işlevlere hizmet veren, çok amaçlı salonlarda; birbiri ile çelişen ve birbirinden çok farklı akustik koşulların, aynı hacim içerisinde sağlanması gerekmektedir.

Bu çalışmada; Gazi Üniversitesi Rektörlük Binası Mimar Kemaleddin Salonu'nda, konferans ve konser için sağlanması gereken akustik koşullar, hacim akustiğine yönelik olarak analiz edilmiş, uluslararası standartlarda ve literatürde önerilen akustik parametrelere göre değerlendirilmiştir.

Restorasyon projesi olması nedeniyle sınırlılıklar dahilinde önlemler alınmıştır. Sınırlılıklar doğrultusunda; görüş düzenlemesi yapılamamıştır. Salon döşemesi eğimsiz olması nedeni ile görüş 
problemleri olacaktır. Projenin iç bükey yüzeylere sahip özgün mimari elemanlarına sınırlılıklar dahilinde herhangi bir müdahale yapılamamıştır.

Uygun olan akustik koşulların sağlanabilmesi amacıyla salonda; duvar, döşeme ve asma tavan malzemelerini kapsayan iyileştirmeler yapılarak salon tasarımı sabit tutulmuş, konferans ve konser işlevlerine yönelik uygun akustik tasarım parametreleri sahnede "Birleşen Hacimler Sistemi (Coupled Volumes System)" ve Akustik Perde Sistemi (Acoustic Curtains) tasarımı aracılığı ile sağlanma yoluna gidilmiştir. Bu bağlamda geliştirilen akustik tasarıma ilişkin ODEON (v 15.14) Simülasyon Programı analizleri ve değerlendirilmeleri her işleve yönelik olarak ayrı ayrı ele alınarak 5. Bölümde verilmiştir.

\section{Kaynaklar}

[1] Wikipedia. Erişim adresi https://tr.wikipedia.org/wiki/Restorasyon_(onarım)

[2] Queirós, D., Calejo Rodrigues, R., \& Pereira, N. (2016). Historical building acoustical retrofit: An experimental examination of traditional wooden floors. Building Acoustics, 23(3).

[3] Iannace, G., Trematerra, P., \& Qandil, A. (2013). The acoustic correction of classrooms in historical buildings with numerical simulation. In AIA-DAGA 2013 Conference on Acoustics (EAA) (pp. 18-21).

[4] Odeon A/S, “Room Acoustics Modelling Software, V 15.00 Auditorium”, Denmark, 2018.

[5] ODEON Material Library, 2018.

[6] Gazi Üniversitesi. Erişim adresi http://gazi.edu.tr/posts/view/title/binamizin-tarihi-219

[7] Mehta, M., Johnson, J., Rocafort, J., “Architectural Acoustics Principles and Design” Merrill Prentice Hall, 301-306, 1999.

[8] Ahnert, W. and H.P. Tennhardt, "Acoustics for Auditoriums and Concert Halls," in Handbook for Sound Engineers, ed. G.M. Ballou, 4th ed., Elsevier Focal Press, 2008.

[9] Everest, F. A., Pohlmann, K. C., “Master Handbook of Acoustics” McGraw Hill, 2009.

[10] TS EN 60268-16 : 2012-01, "Ses sistem cihazları -Bölüm 16: Konușma iletim indeksi ile konuşma anlaşılabilirliğinin tarafsız sınıflandırılması”, Türk Standartları Enstitüsü, Ankara, 2012.

[11] TS EN ISO 3382-1, "Akustik- Odaların Akustik Parametrelerinin Ölçülmesi - Bölüm 1: Performans Boşlukları”, Türk Standartları Enstitüsü, Ankara, 2010.

[12] Türkmen, R. “Oditoryumlarda Akustik Performansın İyileştirilmesine Yönelik Tasarım Parametrelerinin Geliştirilmesi ve Bir Örneklem” Doktora Tezi, Gazi Üniversitesi, Fen Bilimleri Enstitüsü, Ankara, 2013.

[13] Egan, M. D. “Architectural Acoustics, 1st edition”, J. Ross Publishing Inc., Fort Lauderdale, 2007.

[14] Barron, M., “Auditorium Acoustics and Architectural Design”, Spon Press, 2010.

[15] Çevre ve Orman Bakanlığı, "Çevresel Gürültünün Değerlendirilmesi ve Yönetimi Yönetmeliği (ÇGDYY)”, Resmi Gazete, Türkiye, 2011.

[16] Cowan, J., “Architectural Acoustics Design Guide”, Mc Graw Hill, 2000.

[17] Özkartal, E. "Konser Salonlarında Akustik Konfor Parametrelerinin Analizi Ve Bir Örnek Çalışma” Yüksek Lisans Tezi, Gazi Üniversitesi, Fen Bilimleri Enstitüsü, Ankara, 2011.

61 | P a g e

www.iiste.org 
[18] Demirel,F., İlisulu.S.G., Özçetin,Z., "Acoustic Performance Study For The Conference Hall of Ministry of Environment and Urbanizaton Service", Journal of Polytechnic (E - SCI), 21(1)(4753), 2018.

[19] DemireL,F., İlisulu, G., Görkem,M., "Acoustic Design of Sivas Cultural Center Multipurpose Hall”, Journal of Polytechnic (E - SCI), 21(3)(535-542), 2018.

[20] Demirel, F., Mimari Akustik Yayınlanmamış Ders Notları, Gazi Üniversitesi Mimarlık Fakültesi, Ankara, 2020. 